\title{
8. SITES 246 AND 247
}

\author{
The Shipboard Scientific Party ${ }^{1}$
}

\section{SITE DATA}

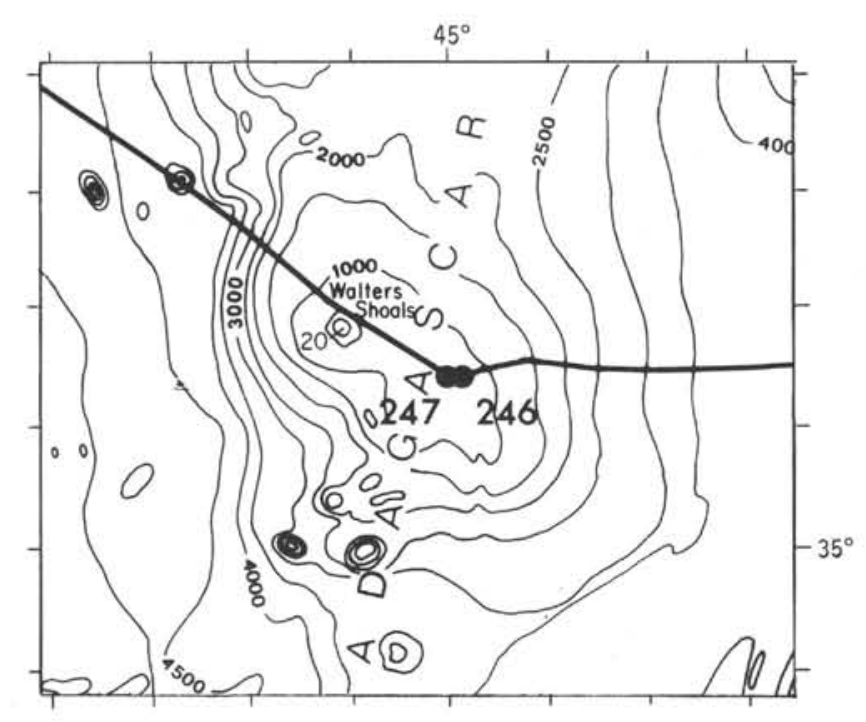

Location: Madagascar Ridge

Position:

$$
33^{\circ} 37.21^{\prime} \mathrm{S}, 45^{\circ} 09.60^{\prime} \mathrm{E} \text { (246) }
$$

$33^{\circ} 37.53^{\prime} \mathrm{S}, 45^{\circ} 00.68^{\prime} \mathrm{E}$ (247)

Water Depth:

1030 meters (246)

944 meters (247)

Total Penetration:

203 meters (246)

26 meters (247)

Cores: 11 cores (94 m cut, $23.8 \mathrm{~m}$ recovered) (246)

1 core ( $8 \mathrm{~m}$ cut; only core catcher recovered) (247)

Deepest Unit Recovered: Glauconitic calcareous sand of early early Eocene age

\footnotetext{
${ }^{1}$ Roland Schlich, Institut de Physique du Globe, Saint-Maur-desFossés, France; E. S. W. Simpson, University of Capetown, Rondebosch, South Africa; Joris Gieskes, Scripps Institution of Oceanography, La Jolla, California; W. A. Girdley, Mesa College, Grand Junction, Colorado; Lucien Leclaire, Muséum National d'Histoire Naturelle, Paris, France; B. Vaughn Marshall, U.S. Geological Survey, Menlo Park, California; Casey Moore, University of California, Santa Cruz, California; Carla Müller, Johann-WolfgangGoethe-Universität, Frankfurt, Germany; Jacques Sigal, Institut Français du Pétrole, Rueil-Malmaison, France; T. L. Vallier, Scripps Institution of Oceanography, La Jolla, California; Stan M. White, California State University, Fresno, California; Barbara Zobel, Bundesanstalt für Bodenforschung, Hannover, Germany.
}

\section{BACKGROUND AND OBJECTIVES}

One of the characteristics of the Indian Ocean which serves to distinguish it from the Atlantic and Pacific oceans is the abundance of aseismic, relatively shallow, flattopped, often sediment-covered and steep-sided ridgeor plateau-like morphological features which have been termed "microcontinents" by Heezen and Tharp (1965) and "oceanic ridges" by Udintsev (1965).

The limited geological and geophysical data available suggest that these features may represent more than one type of crustal structure and composition, and Laughton, Matthews, and Fisher (1970) have proposed the following provisional classification of the Indian Ocean aseismic ridges and plateaus. (Those marked with an asterisk are located in the western part of the Indian Ocean between Africa and the seismically active mid-ocean ridge.)

Continental in origin: *Seamount chain southeast of Socotra, *north part of Mascarene Plateau, *Mozambique Ridge, *Madagascar Ridge, *Agulhas Plateau, Crozet Plateau (?), Kerguelen Plateau (?), Broken Plateau (?), Naturaliste Plateau (?), Wallaby Plateau (?).

Linear volcanic features: Chagos-Laccadive Ridge, *south part of Mascarene Plateau.

Uplifted oceanic crust: Ninetyeast Ridge.

Several attempts have been made to drill three of these features (Leg 22: Sites 214, 216, 217; Leg 26: Sites 253, 254 on the Ninetyeast Ridge; Leg 23: Site 219 on the Laccadive-Maldive Ridge; and Leg 24: Site 237 on the Mascarene Plateau).

Flexotir reflection data obtained by Schlich et al. (1971) on the Kerguelen-Heard Plateau suggest a possible continental structure for this feature.

Some of the microcontinents (e.g., the Seychelles Bank at the northern end of the Mascarene Plateau) are evidently at least partly granitic, and gravity measurements show them to be in isostatic equilibrium, hence crustal thickness varies inversely with depth below sea level. It has been suggested that some microcontinents, such as Broken and Naturaliste plateaus, represent the result of crustal thinning (Francis and Raitt, 1967). More evidence relating to microcontinental basement composition and age and history of their vertical movements is clearly necessary to throw some light on the problem. The Mozambique and Madagascar ridges are obvious sites for deep-sea drilling with this major objective.

Figure 1 shows that both the Madagascar and Mozambique ridges are 1000 to 2000 meters deep and trend southward continuously from Madagascar and the "Mozambique bulge" of southeastern Africa, respectively. Both are shallowest ( $<1000$ and $20 \mathrm{~m}$, respectively) near the southern end and both terminate abruptly with bold squared-off bluffs at about $35^{\circ} \mathrm{S}$. They are separated by the 5000-meter-deep, 300-mile-wide Mozambique Basin, 


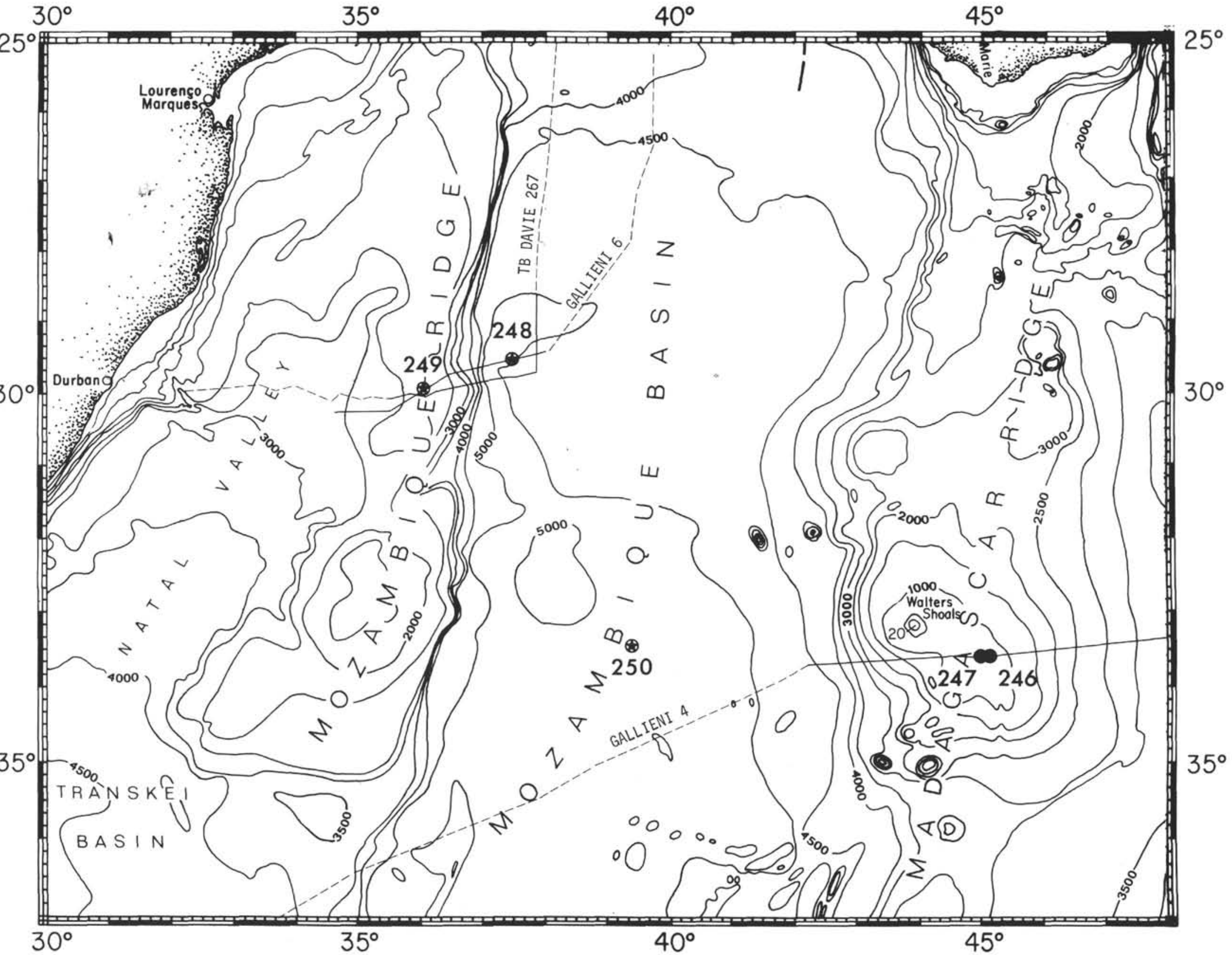

Figure 1. Bathymetric chart showing major morphological features and deep-sea drilling site locations between Madagascar Ridge and southeast Africa. Isobaths are drawn at 500-meter intervals. Tracks of ships providing survey data for Sites 246 and 247 are indicated (solid iine). 
towards which they are bounded by steep scarps. By contrast, the eastern flank of the Madagascar Ridge slopes gently down to the southern Madagascar Basin, while the western flank of the Mozambique Ridge follows a gradual descent into the Natal Valley which separates the southern part of the ridge from the steep continental margin of southeastern Africa. The gross morphological features described above are strongly suggestive of very large-scale vertical block faulting and tilting. The deep Mozambique Basin shallows progressively north of about $27^{\circ} \mathrm{S}$, merging with the 3000-meter-deep Mozambique Channel which separates the Madagascar and African continental blocks.

Seismic reflection data (flexotir) were obtained by Gallieni 4 in 1971 along a profile almost due west across the Madagascar Ridge at a latitude of about $33^{\circ} 30^{\prime} \mathrm{S}$ (Figure 1). The profile started in the Madagascar Basin at a water depth of about 4000 meters and ended in the Mozambique Basin at a depth of 4400 meters. The sediment cover on the eastern flank of the Madagascar Ridge thickens progressively along the upward slope and reaches a maximum of about $0.8 \mathrm{sec}$ DT (double way time) at $46^{\circ} 45^{\prime} \mathrm{E}$ and then decreases again towards the eastern edge of the ridge. On the ridge crest, the sediment cover is even less thick (about $0.3 \mathrm{sec}$ DT) and the sediment nearly disappears at $44^{\circ} 45^{\prime} \mathrm{E}$. Wide-angle reflection and refraction sonobuoy data, obtained by Gallieni along this profile, suggest for the material just underlying this strong continuous reflector, a high sonic velocity of about 5 $\mathrm{km} / \mathrm{sec}$. Deeper reflections can be seen on the flexotir record, but their origins remain uncertain since they cannot be followed all along the profile.

The site on the Madagascar Ridge, provisionally located in position $33^{\circ} 37^{\prime} \mathrm{S}, 45^{\circ} 15^{\prime} \mathrm{E}$ is situated on the crest itself (0800 GMT, Figure 2). At this location, the high velocity layer $(5 \mathrm{~km} / \mathrm{sec})$ lies at a depth of about $0.5 \mathrm{sec}$ DT.

The objectives of drilling a hole on the Madagascar Ridge were to reach and sample the high velocity layer (5 $\mathrm{km} / \mathrm{sec}$ ) at about $0.5 \mathrm{sec}$ DT, which may be ridge basement or the upper surface of hard layered sediments overlying basement, and to sample the sediments as completely as possible in order to establish a high midlatitude biostratigraphic succession above the carbonate compensation depth (CCD).

\section{SURVEY DATA AND OPERATIONS}

Glomar Challenger departed from Site 245 at 0130 hours LT (local time) on 7 August 1972 (2230 GMT on 6 August), and after about 33 hours of steaming in a southwesterly direction at a reduced speed of about 5 knots in 30-foot swells, reached a proposed intermediate site located at about $33^{\circ} 30^{\prime} \mathrm{S}, 50^{\circ} 00^{\prime} \mathrm{E}$ in the extreme southern part of the Madagascar Basin. Because of unfavorable weather conditions (18-foot swells) and no immediate prospect of improvement, it was decided to abandon this intermediate site, and at 1100 LT (0800 GMT) on 8 August 1972 , course was altered to $280^{\circ}$ in the direction of Site 246 , which is located near the crest on the east flank of the Madagascar Ridge. The proposed site $\left(33^{\circ} 35^{\prime} \mathrm{S}, 45^{\circ} 15^{\prime} \mathrm{E}\right)$, at a water depth of about 1100 meters, was approached along a course of $250^{\circ}$ and crossed at about 1700 LT (1400 GMT) on 9 August 1972. The airgun reflection profile was continued in the same direction at a speed of about 10 knots for approximately 9 miles. At 1755 LT (1455 GMT), Glomar Challenger reversed course to $078^{\circ}$ and reduced speed to improve the quality of the airgun records. At 1906 LT (1606 GMT), a suitable location was reached. The $16-\mathrm{kHz}$ beacon was dropped under way above the identified site and immediately after the airguns, hydrophones, and magnetometer had been brought onboard, the ship returned to the beacon to take up station. The geographic coordinates of Site 246 are: $33^{\circ} 37.21^{\prime} \mathrm{S}, 45^{\circ} 09.60^{\prime} \mathrm{E}$ (Figure 3).

The Glomar Challenger airgun reflection profile obtained in the near-site area almost coincides with the Gallieni flexotir reflection profile. Both records show a series of well-stratified layers following more or less the gentle upward slope of the east flank of the Madagascar Ridge. The different reflectors observed on the flexotir record (Figure 2) can be recognized on the airgun records with the exception of the lowest which does not always appear very clearly on the Glomar Challenger record. At Site 246, the acoustic basement, which according to the Gallieni data corresponds to the high velocity layer (5 $\mathrm{km} / \mathrm{sec}$ ), is hardly visible but can be vaguely detected on the original large scale airgun record at about $0.3 \mathrm{sec}$ DT depth (Figure 4).

The main site objective was to reach and sample the high velocity layer $(5 \mathrm{~km} / \mathrm{sec})$ at about $0.3 \mathrm{sec}$ DT. Since this site is above the CCD, a nearly continuous coring program was proposed in order to sample the sediment section as completely as possible.

Drilling and coring at this site started at 2345 (LT) on 9 August 1972 and ended at 1230 (LT) on 10 August 1972. Eleven cores were taken between 0 and 194 meters subbottom depth. The total cored section is 94 meters and the total core recovered is 23.8 meters (Table 1 ). The sediments cored are mainly unconsolidated foraminiferal and glauconitic sands, which may explain the poor core recovery despite using the plastic sock and "rat trap" core catchers. At a subbottom depth of 203 meters, while making a pipe connection, 9 meters of hole caved in and the decision was taken, for technical reasons relating to hole instability, to abandon the site. The total time spent on the site was about 18 hours. The average drilling rate was $109 \mathrm{~m} / \mathrm{hr}$, and the average coring rate was $24.1 \mathrm{~m} / \mathrm{hr}$. After completion of drilling and coring, the four-cone bit appeared to be in very good condition.

Since the objective to reach and sample the high velocity layer at $0.33 \mathrm{sec}$ DT (about $300 \mathrm{~m}$ ) was not achieved, it was decided to drill a second hole at a nearby location where it could be expected that the unconsolidated sand layers would be less abundant. Glomar Challenger departed from Site 246 at 1720 LT (1420 GMT) on 10 August 1972 in the direction of Site 247, located about 8 miles west of Site 246. Immediately after departure, the airguns, hydrophones, and magnetometer were streamed and the profile was continued at a speed of about 6 to 7 knots. After 1 hour of steaming, a suitable location close to the crest of the Madagascar Ridge was found. The airgun reflection profile was continued in the same direction at a speed of about 7 knots for about 7 miles. At 1929 LT (1629 GMT), Glomar Challenger 

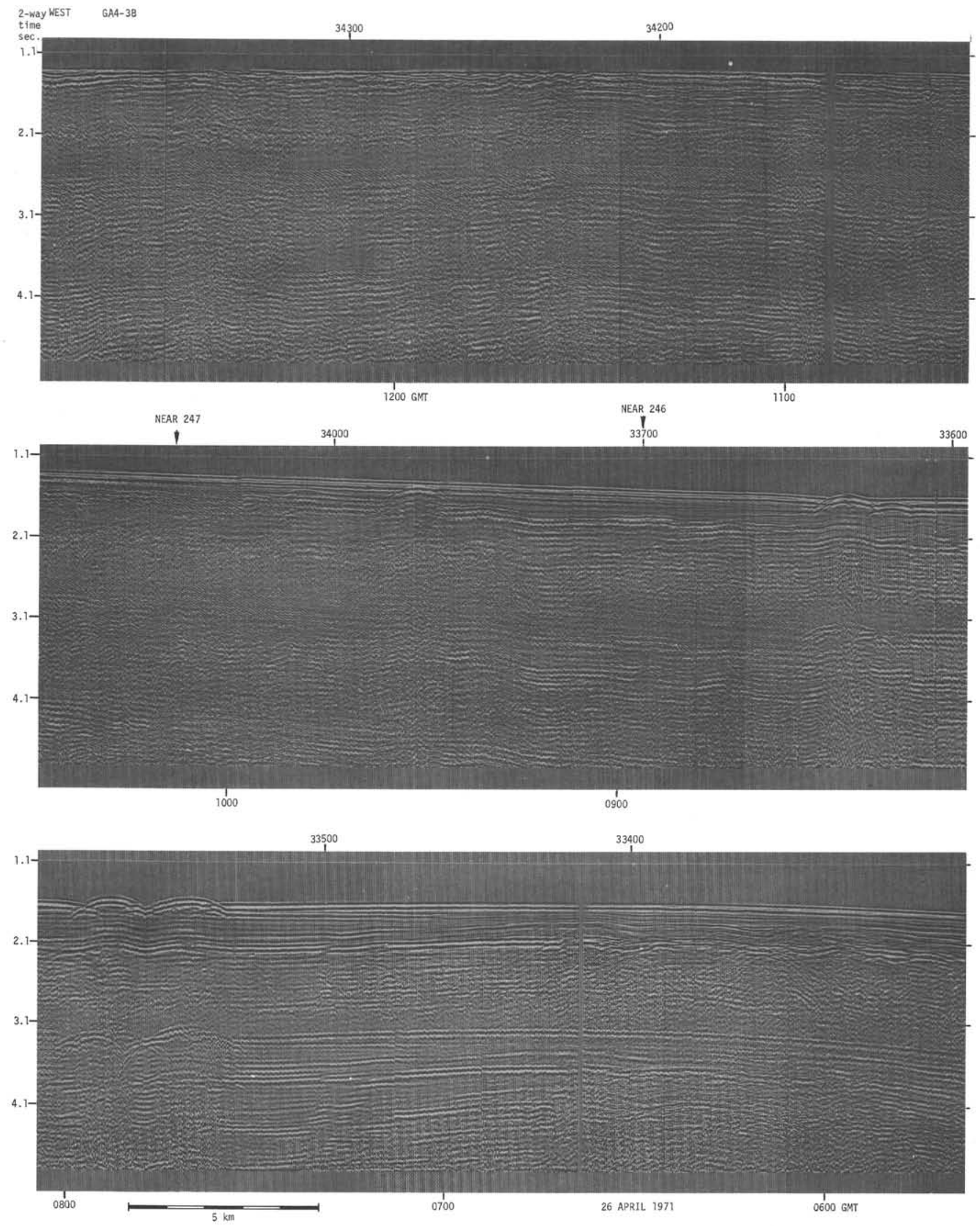

Figure 2. Gallieni 4 seismic reflection profile (flexotir sound source and variable area recording) in the vicinity of Sites 246 and 247. The location of this section is given in Figure 1. Gallieni 4 records are from unpublished Institut de Physique du Globe and Comité d' Études Pétrolières Marines data (Schlich personal communication). 


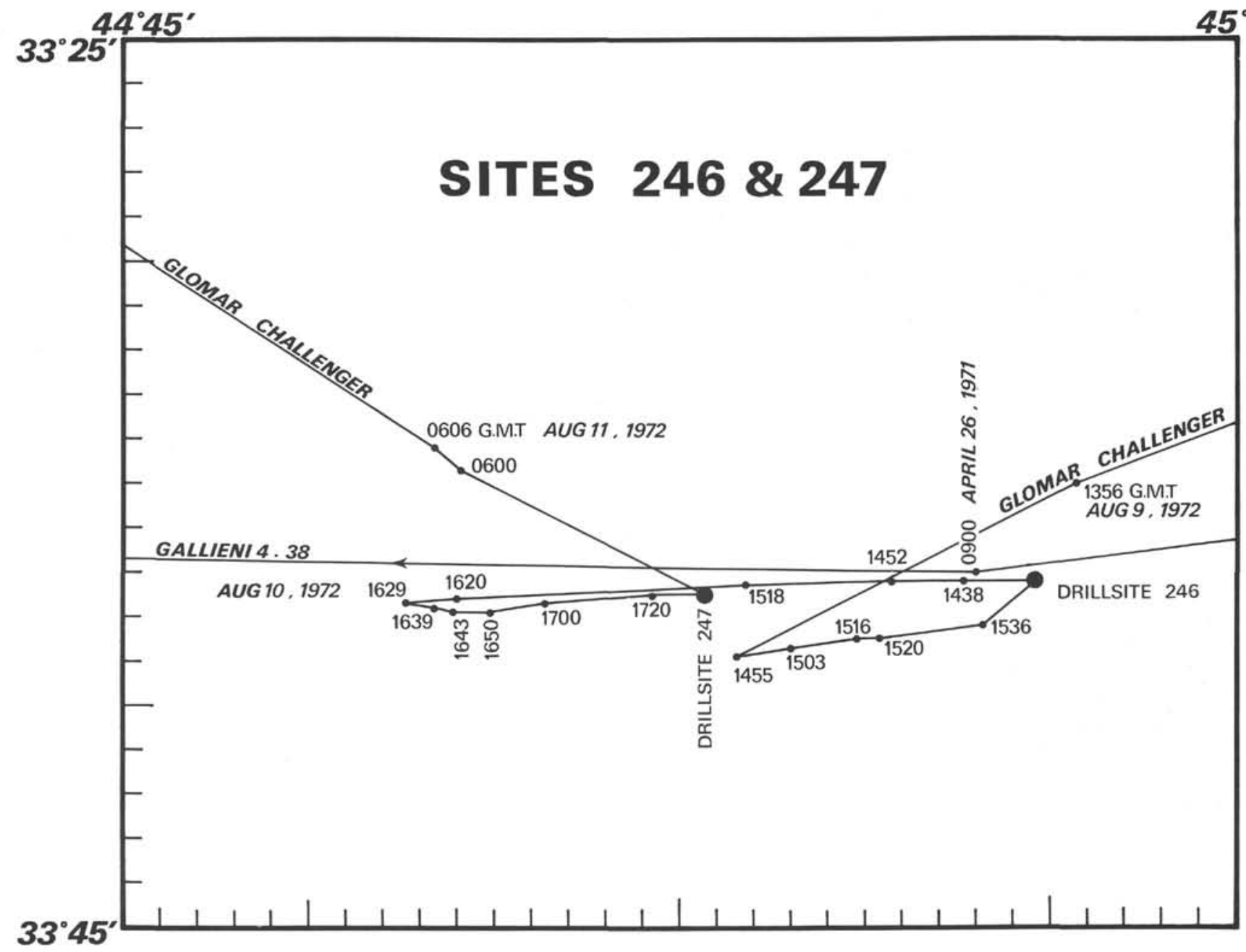

Figure 3. Details of the Glomar Challenger site approach.

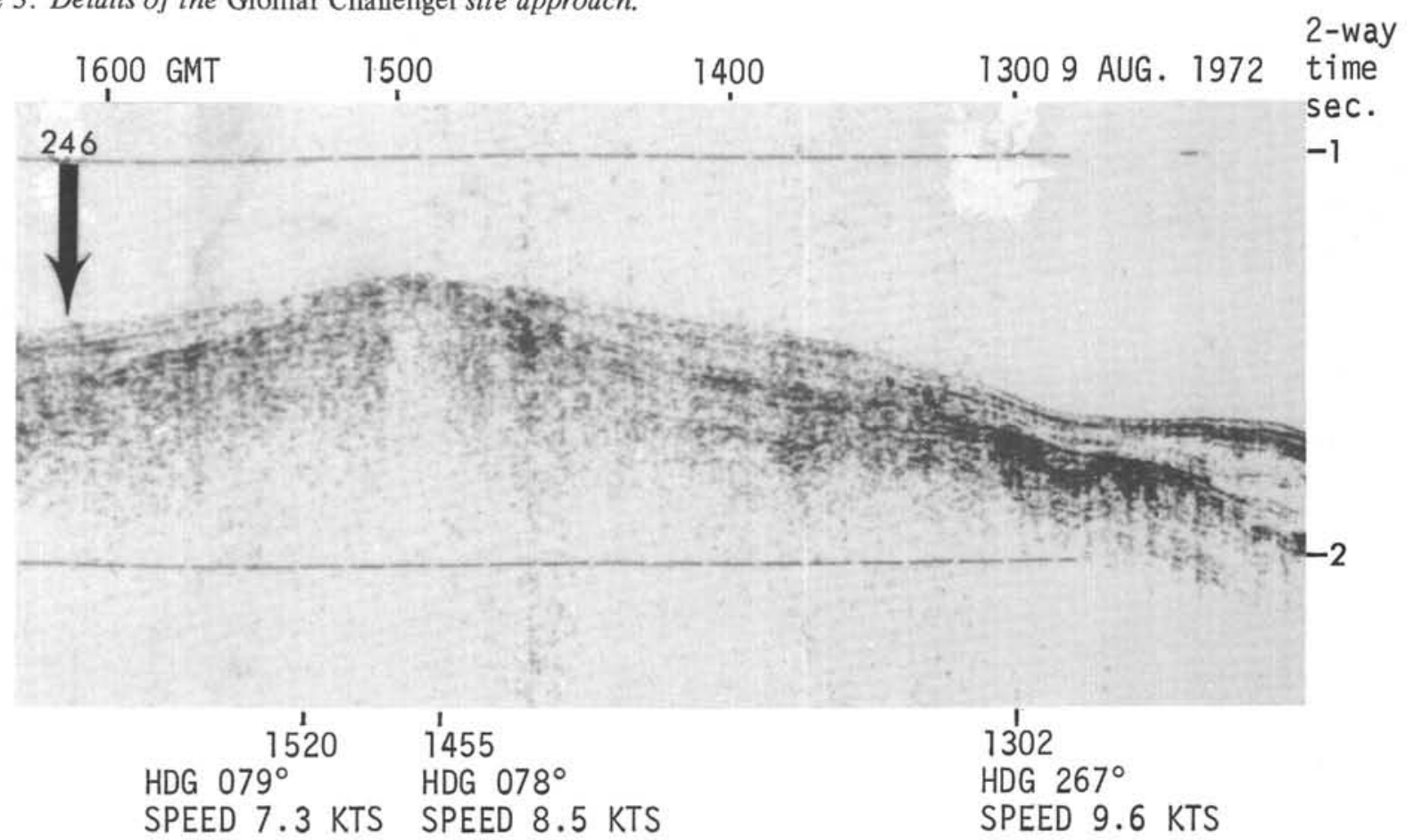

Figure 4. Glomar Challenger seismic reflection profile on approach to Site 246. 
TABLE 1

Coring Summary, Site 246

\begin{tabular}{ccccc}
\hline Core & $\begin{array}{c}\text { Depth Below } \\
\text { Sea Floor } \\
(\mathrm{m})\end{array}$ & $\begin{array}{c}\text { Cored } \\
(\mathrm{m})\end{array}$ & $\begin{array}{c}\text { Recovered } \\
(\mathrm{m})\end{array}$ & $\begin{array}{c}\text { Recovery } \\
(\%)\end{array}$ \\
\hline 1 & $0-4$ & 4 & CC & 0 \\
2 & $52-61$ & 9 & CC & 0 \\
3 & $80-89$ & 9 & CC & 0 \\
4 & $119-128$ & 9 & 0.5 & 6 \\
5 & $128-137$ & 9 & 9.0 & 100 \\
6 & $137-146$ & 9 & CC & 0 \\
7 & $146-155$ & 0 & 0.0 & 0 \\
8 & $155-164$ & 9 & 0.5 & 6 \\
9 & $164-173$ & 9 & 9.3 & 100 \\
10 & $176-185$ & 9 & 1.8 & 20 \\
11 & $185-194$ & 9 & 2.7 & 30 \\
Total & & 94 & 23.8 & 25 \\
\hline
\end{tabular}

Note: Echo sounding depth (to drill floor) $=1040$ meters; drill pipe length to bottom $=1045$ meters.

reversed course and reduced speed to about 6 knots at 2020 LT (1720 GMT) to enhance the clarity of the reflection profiler records. At 2033 LT (1733 GMT) on 10 August 1972 , the selected site was reached, and the $13.5 \mathrm{kHz}$ beacon was dropped under way above the identified location. Immediately after the airguns, hydrophones, and magnetometer were retrieved, the ship reversed course to take up station. The geographic coordinates of Site 247 are: $33^{\circ} 37.53^{\prime} \mathrm{S}, 45^{\circ} 00.68^{\prime} \mathrm{E}$ (Figure 3).

At Site 247, like Site 246, the acoustic basement, which according to the Gallieni data corresponds to the high velocity layer $(5 \mathrm{~km} / \mathrm{sec})$, can hardly be distinguished on the airgun record. A very weak and discontinuous reflector can be vaguely detected on the large-scale original airgun record at about $0.2 \mathrm{sec}$ DT and may correspond to the top of this layer (Figure 5).

Drilling and coring at this site started at 0110 (LT) on 11 August 1972 and ended at about 0400 (LT). Only one core, with very poor recovery (core catcher only), was taken between 0 and 8 meters below the sea floor (Table 2). At a depth of 26 meters below the mud line, very hard sediments were encountered and drilled for 20 minutes with full water pressure, $10-20,000 \mathrm{lb}$ bit weight, and slow rotation of the drill string. No penetration was achieved, and in view of the very real possibility of losing the unsupported bottom hole assembly, the decision was made to abandon the hole and the area in general. A bent bumper-sub later confirmed the wisdom of not attempting to penetrate the hard layer at shallow depth. Total time spent on the site was 11.5 hours.

Glomar Challenger left Site 247 at 0810 LT (0510 GMT) on 11 August 1972 in a northwesterly direction at a speed of 6 knots while the airguns, hydrophones, and magnetometer were streamed. At about 0900 LT $(0600$ GMT), the speed was increased to maximum, and the ship steamed in the direction of Site 248.

\section{LITHOLOGY}

\section{Introduction}

Eleven cores were taken during the drilling of Hole 246 to a depth of 194 meters below the sea floor. Ten of the 11

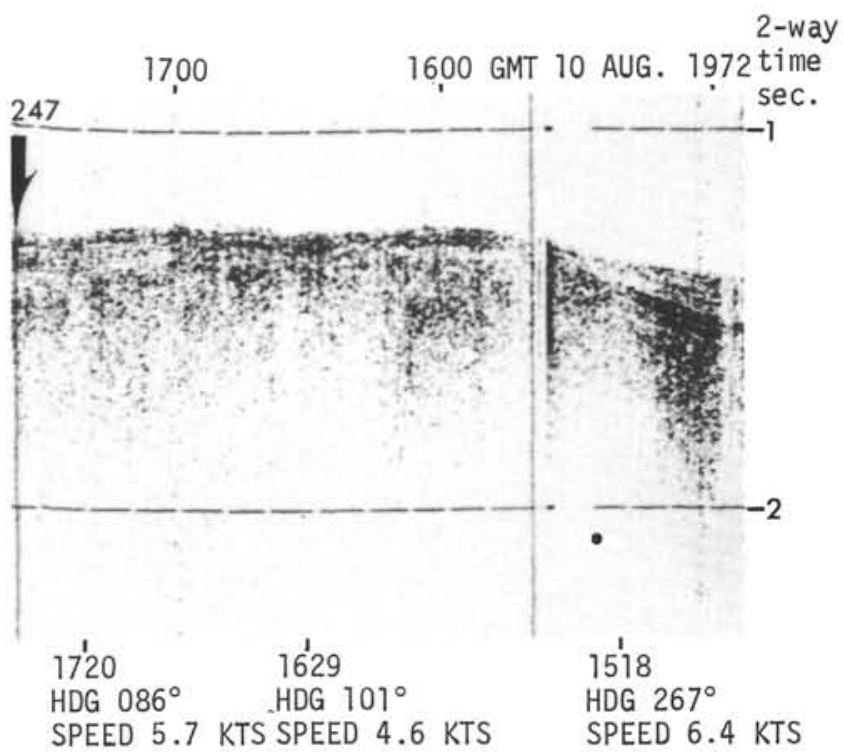

Figure 5. Glomar Challenger seismic reflection profile on approach to Site 247.

cores recovered sediment which can be subdivided into three lithostratigraphic units (summarized in Table 3 and Figure 6).

\section{Description of Lithologic Units}

\section{Unit I: Foram Ooze (Cores 1 through 3)}

Unit I is dominantly composed of sand-size foram ooze with minor nanno-foram ooze. Semilithified particles of foram chalk-ooze (Core 3) demonstrate that the foram ooze is not necessarily a washed residue of a nanno-foram mixture.

The foram ooze from Core 1 contains 20 percent detrital silt in addition to a barnacle and foraminifera of the upper shelf environment. The data indicate that the sediment is at least partially allochthonous. In contrast, Cores 2 and 3 include no obviously detrital sediment.

Pyrite occurs in Core 3 as megascopic fragments up to 1 $\mathrm{cm}$ in diameter with included foraminifera. At this depth $(80 \mathrm{~m})$, pyrite formation can be expected through oxygen depletion (during decomposition of foraminifera) allowing sulphate-reducing bacteria to produce sulphite.

\section{Unit II: Shelly Carbonate Sand (Cores 4 through 9)}

The boundary between Units I and II $(125 \mathrm{~m})$ is defined by a highly lithified pebbly calcareous volcanic sandstone.

TABLE 2

Coring Summary, Site 247

\begin{tabular}{ccccc}
\hline Core & $\begin{array}{c}\text { Depth Below } \\
\text { Sea Floor } \\
(\mathrm{m})\end{array}$ & $\begin{array}{c}\text { Cored } \\
(\mathrm{m})\end{array}$ & $\begin{array}{c}\text { Recovered } \\
(\mathrm{m})\end{array}$ & $\begin{array}{c}\text { Recovery } \\
(\%)\end{array}$ \\
\hline $\begin{array}{c}\text { Total } \\
\text { To }\end{array}$ & $0-8$ & $\frac{8}{8}$ & $\frac{\mathrm{CC}}{0.0}$ & $\frac{0}{0}$ \\
\hline
\end{tabular}

Note: Echo sounding depth (to drill floor) $=954$ meters; drill pipe length to bottom $=955$ meters . 
TABLE 3

Lithologic Units, Site 246

\begin{tabular}{c|c|c}
\hline Depth & Lithologic Units & Thickness (m) \\
\hline 125 & $\begin{array}{c}\text { I } \\
\text { Foram ooze with minor } \\
\text { foram nanno ooze }\end{array}$ & 125 \\
\hline 176 & $\begin{array}{c}\text { II } \\
\text { III }\end{array}$ & 51 \\
& $\begin{array}{l}\text { Shelly carbonate sand } \\
\text { volcanic sand and volcanic } \\
\text { breccia; minor silty clay and } \\
\text { limestone }\end{array}$ & 18 \\
194 & & \\
\hline
\end{tabular}

The dominant lithology of Unit II below the lithified layer is shell-rich to shelly carbonate sand with minor amounts (0\%-10\%) of glauconite. Shelly carbonate sand characterizes Cores 4 and 9, whereas Cores 6 and 8 are composed of shell-rich carbonate sand. Nowhere do siliceous detrital grains (dominantly potassium feldspar) exceed 20 percent of the lithology. Core 4 contains early Miocene and reworked Eocene fauna; Cores 5 to 9 contain only early Eocene fauna.

Unit III: Carbonate Sand and Volcaniclastics (Cores 10,11)

Glauconite-bearing to glauconite-rich carbonate sands and shelly/zeolite-rich volcanic sand characterize most of Unit III. Other lithologies include thin $(0.5-3 \mathrm{~cm})$ bedded volcanic sandstone and lithified breccia, silty clay, minor limestone, and volcanic ash beds. The olive green color of the glauconitic beds clearly identifies them as "green sand." The glauconite is usually fresh, showing no brownish alteration rims. One volcanic sandstone (Core 10, Section 2, $95-150 \mathrm{~cm}$ ) exhibits cross-bedding. The sediments of Unit III show no obvious evidence of reworking since the formation of glauconite.

\section{Petrography of Volcaniclastic Sediments}

The prominent volcaniclastic layers occurring in Cores 10 (Sections 1 and 2) and Core 11 (Section 1) have been studied in detail by thin section methods. Particulate matter, which is primarily volcanic glass, ranges in size from small pebbles (Core 11) to fine sand and silt. This detrital volcanic glass is dominantly cemented by sparry calcite. Minor constituents include chlorite, feldspar, clay, and probably zeolites.

Most of the volcanic glass is colorless, though some is yellow to reddish. Palagonite is abundant locally, exhibiting perlitic texture. Individual volcanic particles show irregular shape. The volcanic glass may be clear with only an alteration rim or include microlites or feldspathic spherulites. The latter show well-developed polarization crosses under crossed nicols. Mineral grains, occurring in trace abundances, include green chlorite, plagioclase with albite twinning, and probable potassium feldspar.
While volcanic detritus comprises up to 85 percent of these rocks, most of the remainder is calcite. Calcite occurs both as an interstitial cement, and to a lesser degree, as a secondary replacement of mineral grains or fossils (radiolarians?).

\section{Lithologic Interpretations}

1) Large shallow-water pelecypod fragments, crossbedded sand, and glauconite suggest that the sediments of Units II and III accumulated in an agitated, relatively shallow-water environment (probably less than $300 \mathrm{~m}$ ) (Porrenga, 1967). Terrigenous influx was low excepting periods of volcanic supply. A possibly similar depositional environment may presently exist in the vicinity of Walters Shoals ( $20 \mathrm{~m}$ deep), 60 miles distant from Site 246.

2) A profound hiatus (30 m.y.) occurs within Unit II between Cores 4 and 5 , yet no lithologic change was noted at this point. Therefore, it is likely that the Miocene calcareous sand of Core 4 is reworked from identical lower Eocene sediments (Cores 5-9).

3) During early Miocene the sea floor in the area around Site 246 subsided from less than 300 meters to a depth sedimentologically indistinguishable from its present depth (about $1000 \mathrm{~m}$ ). The accumulation of dominantly foram ooze from Miocene to Recent suggests the possibility of winnowing of nannofossils by bottom currents.

\section{PHYSICAL PROPERTIES}

Physical property data are very limited. GRAPE bulk density measurements were run on three cores; sonic velocity tests were made on Cores $4,9,10$, and 11 ; and two successful thermal conductivity tests were run in calcareous sand. The bulk density and thermal conductivity value for the sand are probably low because of drilling disturbance.

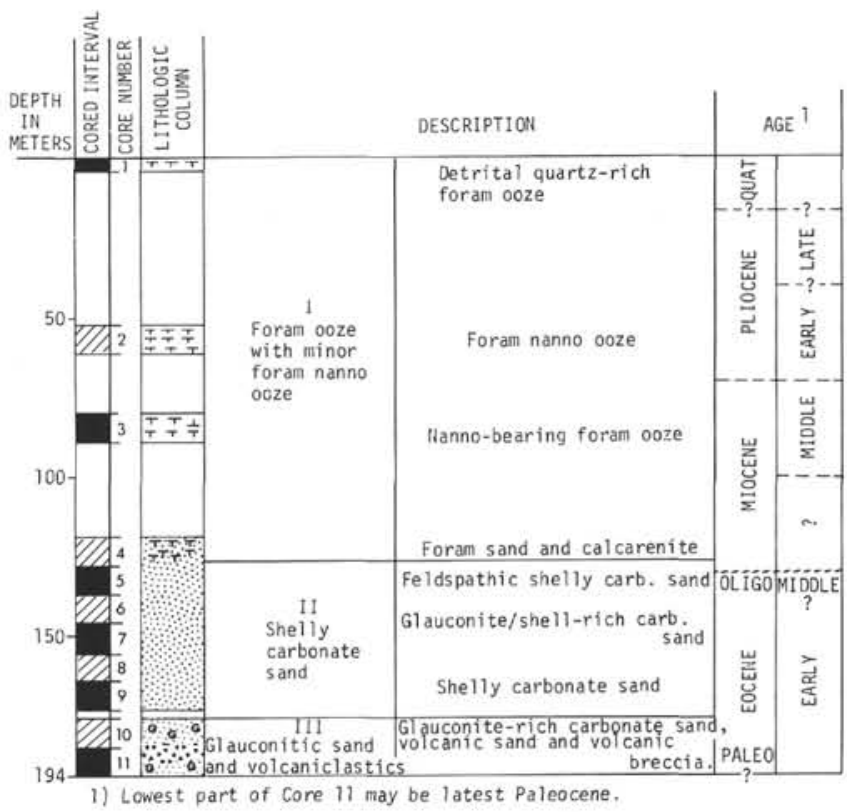

Figure 6. Stratigraphic column, Site 246. Dashed lines indicate uncertain boundaries and the wavy line indicates a hiatus. 


\section{BIOSTRATIGRAPHY}

Calcareous Nannoplankton

Quaternary

The assemblage in the core catcher of Core 1 indicates the Emiliania huxleyi Zone (NN21) of Quaternary age (Figure 7). The most frequently occurring species are Gephyrocapsa oceanica, Emiliania huxleyi, Oolithotus fragilis, Umbilicosphaera mirabilis and Cyclococcolithus leptoporus.

\section{Neogene}

The core catcher of Core 2 contains a nannoplankton assemblage of the early Pliocene, Ceratolithus rugosus Zone (NN13) with Ceratolithus rugosus, Ceratolithus tricorniculatus, Discoaster brouweri, Discoaster pentaradiatus, Reticulofenestra pseudoumbilica and many species of the genus Scyphosphaera.

The core catcher of Core 3 belongs to the early Miocene, but an exact age determination is not possible.

\section{Paleogene}

In Cores 4 to 11 , nannoplankton are missing or are very poorly represented, which doesn't allow an age determination. Preservation is very poor. The few species of these cores indicate the Eocene, but it is not possible to give the zones.

\section{Foraminifera}

\section{Quaternary and Neogene}

Because of technical difficulties the Quaternary and Neogene section penetrated in this hole yielded very few samples. This is the more regrettable since at this site a complete, undissolved calcareous Neogene section from a southern temperate region was to be expected. From Cores 1 through 3 there were core catcher samples only. In Core 4 , there was only the mixed assemblage that remained when the entire core was washed out of the pipe. Core 5 was the first core with good recovery.

The planktonic foraminifera of $1, \mathrm{CC}$ are at least partly of Holocene age (Globigerina calida callaa). By far the most specimens of the assemblage belong to four temperate species: Globorotalia inflata, G. hirsuta, G. crassaformis, and $G$. truncatulinoides. There are few Globorotalia cultrata, Sphaeroidinella dehiscens, Globigerinoides ruber, and $G$. sacculifer, which all point to a somewhat warmer environment as indicated by the latter species of Globorotalia. Since we do not know the composition of the recent fauna at the site locality, it cannot be verified that the temperate fauna named above is of Holocene age. It could as well be Pleistocene with a few Holocene elements from the present sea floor. In the fine fraction, there are a few Globigerina? pachyderma, which indicate a cold environment. This would correspond with the findings of Bé and Tolderlund (1971) who describe the region of Site 246 as being still subtropical but relatively near the southern transitional region. There is a rich and diversified benthonic fauna in the core catcher of Core 1, including many large, coarse-grained Lituolacea (Ammobaculites sp., Martinottiella sp., Textularia trochus, Textularia sagittula
246

DEPTH

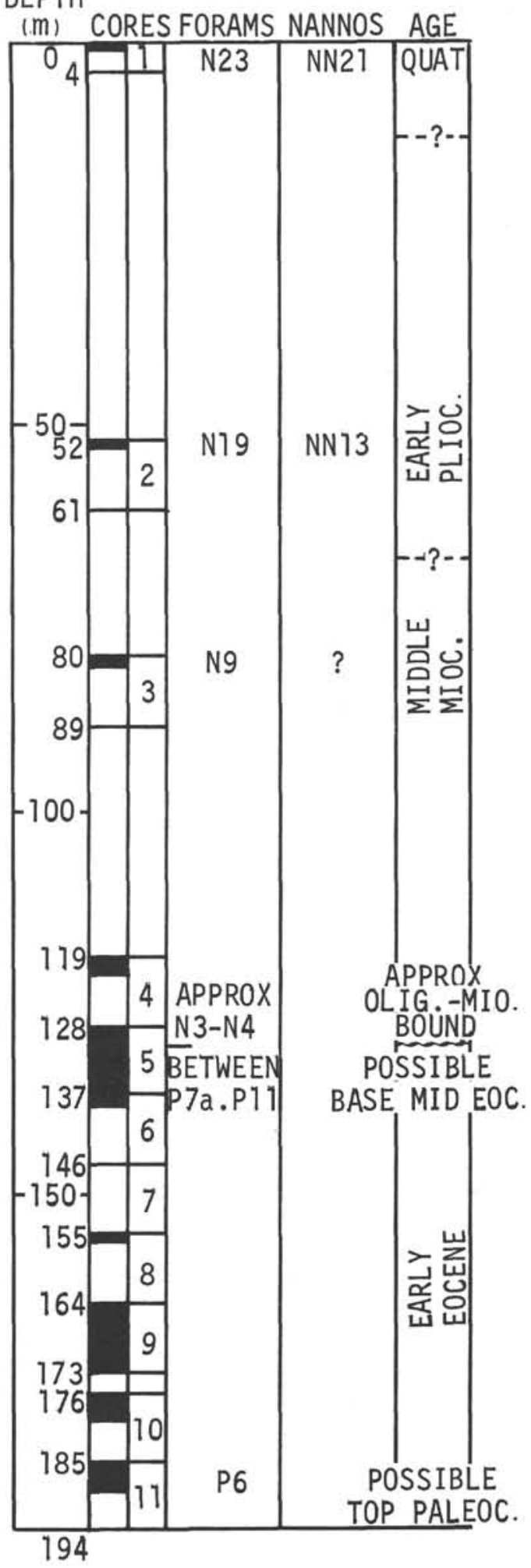

Figure 7. Biostratigraphic column, Site 246. 
fistulosa, Vulvulina pennatula, "Clavulina communis", Karreriella sp., Eggerella sp., Trochamminoides proteus and others), large smooth Miliolacea, large Nodosariacea (mostly Lenticulina spp.; few Rectoglandulina sp.), Cibicides spp., and Discorbacea; common Discanomalina sp., Anomalina semipunctata, and Hoeglundina sp. Besides this rich benthonic foraminiferal assemblage, there are residues of Gastropods, Lamellibranchiata (shallower-water forms like Pecten), worm tubes of different kinds, Ostracoda, Lepas? or other barnacles, Bryozoa, Ophiuroidea, Echinoidea, fish-teeth, and otoliths. Pteropods are not common, represented mostly by Styliola subula, but Limacina inflata, Creseis virgula, and Diacria sp. are also present.

Material of Core 2 (core catcher and some sediment suspended in water; no core recovery) is mostly of Pliocene age and ranges from N.22 down to N.19. Globorotalia inflata and $G$. hirsuta are still the most abundant species and are accompanied by a highly diversified, excellently preserved mixed planktonic assemblage for which Globorotalia margaritae, Globigerina nepenthes, Sphaeroidinellopsis subdehiscens subdehiscens, and Sphaeroidinellopsis grimsdalei give the oldest age and Globorotalia truncatulinoides, the youngest age. There are no Pulleniatina and Sphaeroidinella and nearly no Globoquadrina. The benthonic fauna is relatively poor. Besides fairly deep-living species such as Cibicides wuellerstorfi, Globocassidulina subglobosa, and Gyroidinoides aff. altiformis, it also contains coarsely agglutinated Lituolacea but only in a very small amount.

Non-foraminiferal elements of the fauna are Styliola subula, Limacina inflata, several ostracod species, bryozoans, echinoid spines, and otoliths. The fauna on the whole seems to be purely planktonic, the non-planktonic elements having been introduced by contamination during drilling. A small part of the foraminifera has yellow walls and shows signs of beginning corrosion. These yellowish individuals belong mostly to the stouter species of Globorotalia, which occur also in excellent preservation in the same sample.

The foram sand which constituted Core 3 ran out of the tube when it was taken to the rig floor. Only two buckets of sediment could be saved, one from the lowermost and one from the top part of the core. Although being heavily mixed, these samples show some characteristic differences. The upper part of Core 3 resembles the Core 2 material in development and preservation of the foraminifera. The highly diversified planktonic foraminiferal population ranges in age between at least Quaternary (Globorotalia truncatulinoides) and at most middle Miocene, about the Blow Zones N.10-N.12 (Globorotalia fohsi-group, G. praemenardii praemenardii). The slightly corroded yellowish foraminifera, which occur here as well as in Core 2, yield Globigerinoides sicanus, which means that these yellowish forams are somewhat older than the wellpreserved individuals.

The sample from the lower part of Core 3 contains a higher proportion of Globigerina and Globigerinoides species than in the upper part of the core, whereas the number of well-developed Globorotalia inflata and $G$. hirsuta diminishes; Globorotalia truncatulinoides is absent.
However, this does not mean that the sample is not mixed. There are typical Globorotalia praemenardii archaeomenardii, which give an age of at most N.9/N.8 (lowermost middle Miocene).

The benthonic foraminifera are of no importance either in number of species or as individuals. They usually live in deep basins. The planktonic and part of the benthonic foraminiferal fauna of the core catcher of Core 3 correspond with that of Core 3 . In addition to these, there are some extremely large (several $\mathrm{mm}$ in length) Nodosaria, Lenticulina, Marginulinopsis, Textularia and other serially arranged Lituolacea, together with equally large residues of sessil pelecypods, ?Dentalium, spines of sea urchins, few otoliths, and bryozoa. These are surely constituents which were derived from a shallow-water environment. They do not show much resemblance to the shallow-water residues to be seen in the deeper part of the core. Perhaps they originate from the Recent or near-Recent Walter's Shoals and have come into the core catcher by technical mixing.

A relatively large pyrite aggregate $(\sim 1 \mathrm{~cm})$ was observed in 3 , CC. No incipient pyritization could be seen in the foraminifera. The pyrite aggregate contained excellently preserved small planktonic foraminifera, including Globorotalia fohsi barisanensis.

The mixed sample from Core 4 is totally different from the two cores just described. It contains a very large amount of coarse debris, including well-rounded, polished brown fragments which resemble pea ore. Most of the coarse debris and part of the foraminifera are coated with rust. It is a shallow-water assemblage, slightly reworked, with many Rupertia variabilis, large Vulvulina pennatula, coarse-grained Textularia spp. and other Lituolacea, and very large, poorly preserved Lenticulina sp. The non-foraminiferal assemblage includes Bryozoa colonies, many different species of Lamellibranchiata (including oysters), and decapod crabs. There are no large foraminifera as in Core 5. The planktonic foraminifera are a mixed assemblage. It seems as if there was technical as well as primary mixing. Most of the planktonic foraminifera are of Miocene age; the oldest of these indicate the lower part of the early Miocene (Globorotalia kugleri (v.r.), Globigerina binaiensis (v.r.), Globigerina rohri (c), ?Globigerina ciperoensis, Catapsydrax dissimilis, and Globoquadrina dehiscens dehiscens). Younger forms up to Quaternary in age are mixed into this assemblage. Of more interest are the typical Eocene foraminifera of which very few are represented in the grain-size fraction $>177 \mu$. However, an important part of the planktonic foraminifera of the grain-size fraction $177 \mu-63 \mu$ is furnished by Eocene specimens. This leads to the conclusion that during early Miocene time some sediments of Eocene age were being eroded in an area not far removed from Site 246. Grain-size separation during transport could be the reason for the sole presence of small grain sizes of Eocene material at Site 246.

A sample from the coarse-grained sediment of Core 5 yields a very heterogenous biogenous residue along with the heterogenous inorganic constituents. Mechanically abraded bryozoan colonies, pieces of echinoderms from very different genera, few broken gastropods and pelecypods, large miogypsinid foraminifers, and Rupertia are to be found together with few small benthonic and common 
Paleogene planktonic foraminifera. Very few Globigerinoides trilobus primordius and one individual of Globigerinita stainforthi point to an early Miocene age for the upper part of Core 5. In Section 2 of Core 5, the biogenous components of the grain-size fraction $>160 \mu$ are even more rare. The sample contains uncharacteristic specimens of Globigerina ciperoensis, Globorotalia opima nana?, and Globigerinita aff. unicava. The absence of Globigerinoides points to an Oligocene age. However, since planktonic foraminifera are very rare, it is not certain if the absence of Globigerinoides is real and because further on, the determination of Globorotalia opima nana is questionable, we cannot be too certain about this age.

The very few samples gained at this highly interesting site give the following impressions of sedimentation conditions at Site 246 during the Neogene. During early Miocene time, the site was an area of shallow depth during a marine transgression; nearcoast, partly reworked older sediments, were added continuously to the depositional area. The sea deepened during middle Miocene to Pliocene time and a nearly totally planktonic fauna was deposited. In the Quaternary, a considerable amount of benthonic fauna from lesser depths was added to the planktonic fauna, indicating that (a) an area of considerably higher elevation had been formed in the vicinity, and (b) in addition, the water depth at Site 246 was reduced.

\section{Paleogene $^{2}$}

The Paleogene series was cored almost continuously but with a poor recovery rate for five out of the seven cores. It belongs to the early Eocene (perhaps also the latest Paleocene), with an epicontinental depositional facies.

In addition to the clastic (minerals, rock fragments) or neogenetic (quartz) element, there is also a great deal of biogenic and/or bioclastic material such as bryozoans (which sometimes make up the preponderant part), Echinoids, Lamellibranchia, ostracods, and fish (mainly teeth). In places, very small but entire shells of sea urchins and terebratulaceans occur. Foraminifers are represented by assemblages linked to the facies which contains a limited number of small benthonic species and especially Nummulitidae and Disocyclinidae. Planktonic species are quite limited except in the top and bottom cores.

Larger foraminifera and planktonic species were used to determine a minimum age for the cored series, i.e., the base of the early Eocene or the latest Paleocene for the lowest core (11). For highest levels (Core 5), they do not enable a definite choice to be made between the top part of the early Eocene and the base of the middle Eocene. It is difficult to make a correlation with Site 245 , even though it is nearby, because some important pelagic species were not found in Site 246. Perhaps this is because the sediments are still of early Eocene age. It is to be noted that in descriptions here, faunas are described from older to younger.

\footnotetext{
${ }^{2}$ Work on this section was accomplished with the assistance of $\mathrm{A}$. Blondeau, Professor, University of Paris VI, 11 Quai Saint-Bernard, 75005 Paris and J. Butterlin, Director of Ecole Normale Superieure de Saint-Cloud, 2 Avenue du Palais, 92211 Saint-Cloud, France, as it concerns the larger foraminifera.
}

\section{Analytical Results, Core 11}

This core has several noteworthy features. First, for all the residues obtained, the richness in glauconite gives them a frankly green hue. At the same time, this core alone produced small sized Nummulites and the genus Discocyclina. These larger foraminifera have been examined, respectively, by A. Blondeau and J. Butterlin. All the shells are small in size, mostly quite worn (especially the Nummulites), usually glauconitized, and poorly preserved on the outside. The Nummulites belong to the phylum of $N$. deserti de la Harpe, 1883, which has been found in a well-preserved state in association with Discocylina ( $D$. scalaris) and other Nummulites (N. lahirii, N. kelatensis) in the early Eocene in the Tulear region of Madagascar. The genus Discocyclina is represented by a form similar to $D$. (D.) seunesi Douvillé, 1922 (of Paleocene and base of Eocene) and by a probable D. (D.) archiaci (Schlumberger, 1903) (of early and middle Eocene). It is associated with another species, Asterocyclina stella (Gümbel, 1861), which is of less interest from the stratigraphic standpoint (Paleocene-late Eocene).

The third striking feature of this core is that in the lower parts $(11-2,144-146 \mathrm{~cm} ; 11-2,78-80 \mathrm{~cm})$, there is an important planktonic species, Globorotalia (Morozovella) subbotinae Morozova, 1939. In the other samples examined $(11-2,10-12 \mathrm{~cm} ; 11-1,110-112 \mathrm{~cm}$; and $11-1,30-32 \mathrm{~cm})$, this species is missing. Indeed, the planktonic assemblage becomes less rich.

For the core as a whole, the most common planktonic species are:

Globorotalia (Acarinina) acarinata Subbotina, 1953

Globorotalia (Acarinina) esnaensis (Le Roy, 1953)

Globorotalia (Acarinina) cf. pseudotopilensis Subbotina, 1953

Globorotalia (Acarinina) soldadoensis (Brönnimann, 1952)

Globorotalia (Acarinina) traubi Gohrbandt, 1963

Globorotalia (Morozovella) crassata (Cushman, 1925)

Globorotalia (Morozovella) aequa Cushman and Renz, 1942

Globigerina cf. velascoensis Cushman, 1925

Pseudogloboquadrina primitiva (Finlay, 1947)

The benthonic assemblage (in addition to the larger foraminifera mentioned above) is moderately rich and extremely monotonous. Several species will persist in the ensuing cores. In this sense it is dominated by representatives of the genera Discorbis (including $D$. cf. humilis Le Calvez, 1949), Cibicides, Eponides (including E. cf. ellisorae Garrett, 1939), and Gyroidina, with species probably clinging by their plano-convex or concavo-convex spiral sides, such as are characteristic of these environments. The bottom of the core (Section 2) stands out by the relative abundance of Lagenidae (especially an Astacolus which is close to Hemicristellaria hatchetigbeensis Garrett, 1941, large Nodosaria, and Dentalina). Ostracods are present, but are relatively sparse.

Hence, these levels belong to the bottom of the early Eocene. Any greater accuracy could be based only on negative criteria such as the absence of Globorotalia (Morozovella) velascoensis (which is also known to be scarce in the neighboring Site 245), the absence of 
Globorotalia (M.) aragonensis (which appears only fairly high up with Core 5), and the absence (already found in Site 245) of species such as G. (M.) formosa and G. (M.) wilcoxensis. We can thus conclude that we are in the $G$. (M.) rex Zone, or Blow's Zone P.6, at the base of the early Eocene, although the uppermost Paleocene is not entirely excluded as a possibility. This exists to the extent that the Subzone P.6a, which cannot be characterized here, still belongs to the Paleocene.

Samples examined:

$\begin{array}{ll}11, \mathrm{CC} & 11-1,130 \mathrm{~cm} \text { (thin section) } \\ 11-2,144-146 \mathrm{~cm} & 11-1,110-112 \mathrm{~cm} \\ 11-2,78-80 \mathrm{~cm} & 11-1,30-32 \mathrm{~cm} \\ 11-2,10-12 \mathrm{~cm} & \end{array}$

\section{Analy tical Results, Cores 10 to 6}

These sediments still belong to the same sediment facies and so cannot be dated with any great accuracy. Only Core 10 supplied adequate recovery. Glauconite is not very abundant at the bottom and then disappears. This gives the residues a white color which turns somewhat pink beginning with Core $9(9-4,40-42 \mathrm{~cm})$ and then becomes gray beginning with Core 5 .

As was suggested with regard to Core 11, Nummulites and Discocyclina are no longer found in this core. The only larger foraminifera present are Asterocyclinidae: Asterocyclina stella (Gümbel, 1861) and Asterocyclina speighti (Chapman, 1932). These species, according to J. Butterlin, cannot be used to determine a definite age, i.e., only Paleocene to late Eocene for the former, and questionable early or middle Eocene for the latter.

The small benthonic foraminifers belong to the assemblage already found in Core 11, minus the relatively large Lagenidae. However, they are relatively scarce, especially when biodetritic and clastic residue are abundant. There are also sporadic Textulariidae (including Valvulina cf. bortonica Finlay, 1947) and large-sized Cibicides (C. cf. subspiratus var. limbatus Cita, 1950).

The planktonic assemblage has become "neutral" if we consider the absence of Globorotalia (Morozovella) subbotinae, which was present lower down, and $G$. (M.) aragonensis, which will appear farther up. This assemblage includes an association of new Acarininas with truncatedcone-shaped shells, identical to those found in Site 245. It also includes, among others:

Globorotalia (Acarinina) acarinata Subbotina, 1953

Globorotalia (Acarinina) cf. broedermanni, Cushman and Bermúdez, 1959 (actually a new species already found at Site 245)

Globorotalia (Acarinina) intermedia Subbotina, 1953

Globorotalia (Acarinina) pseudotopilensis Subbotina, 1953

Globorotalia (Acarinina) salisburgensis Gohrbandt, 1967

Globorotalia (Acarinina) soldadoensis (Brönnimann, 1952)

Globorotalia (Acarinina) cf. soldadoensis var. angulosa (Bolli, 1957).

Globorotalia (Acarinina) traubi Gohrbandt, 1967

Globorotalia (Acarinina) gr. triplex Subbotina, 1953

Globorotalia (Morozovella) crassata (Cushman, 1925)
Globigerina cf. velascoensis Cushman, 1925

Pseudogloboquadrina primitiva (Finlay, 1947).

This assemblage is quite similar to the one accompanying the Globorotalia (Morozovella) subbotinae in Core 11. It is probable, although not proven, that these levels attain the G. (M.) formosa Zone or P.7.

Samples examined:

$\begin{array}{ll}10, \mathrm{CC} & 9-4,140-142 \mathrm{~cm} \\ 10-2,130 \mathrm{~cm} \text { (thin section) } & 9-4,40-42 \mathrm{~cm} \\ 10-2,112 \mathrm{~cm} \text { (thin section) } & 9-3,110-112 \mathrm{~cm} \\ 10-2,93 \mathrm{~cm} \text { (thin section) } & 9-3,40-42 \mathrm{~cm} \\ 10-2,57-58 \mathrm{~cm} & 9-2,120-122 \mathrm{~cm} \\ 10-2,10-12 \mathrm{~cm} & 9-2,40-42 \mathrm{~cm} \\ 10-1,110-112 \mathrm{~cm} & 9-1,110-112 \mathrm{~cm} \\ 9, \mathrm{CC} & 9-1,40-42 \mathrm{~cm} \\ 9-6,120-122 \mathrm{~cm} & 8, \mathrm{CC} \\ 9-6,40-42 \mathrm{~cm} & 8-1, \text { undetermined } \\ 9-5,120-122 \mathrm{~cm} & 6, \mathrm{CC}\end{array}$

Analy tical Results, Core 5

This core is still in a neritic sediment facies, with a great deal of clastic and especially biodetrital material, and little or no glauconite. The large and small benthonic species are the same as deeper down in the hole. However, Cassidulina and Allomorphina are present, perhaps indicating a slight deepening. Asterocyclinas are scarces as a rule, and some of them often appear to be reworked with a brown and highly ferruginous test among individuals with fresher uncolored tests.

The planktonic assemblage is appreciably different from the one in the underlying cores. In addition to the truncated-cone Acarinina group, already mentioned, we find:

Globorotalia (Acarinina) broedermanni Cushman and Bermúdez, 1959

Globorotalia (Acarinina) cf. broedermanni Cushman and Bermúdez, 1959

Globorotalia (Acarinina) soldadoensis (Brönnimann, 1952)

Globorotalia (Acarinina) soldadoensis var. angulosa (Bolli, 1957)

Globorotalia (Acarinina) triplex Subbotina, 1953

Globorotalia (Morozovella) quetra Bolli, 1957

Globigerina pseudoeocaena Subbotina, 1953

Globigerina sp. (cf. "Globigerinoides" higginsi Bolli, 1957)

Pseudogloboquadrina primitiva (Finlay, 1947)

Pseudohastigerina wilcoxensis (Cushman and Ponton, 1932).

In addition a minimum age is given by the presence of several specimens of $G$. (Morozovella) aragonensis Nuttall, $1930(5-6,110-112 \mathrm{~cm} ; 5-5,70-72 \mathrm{~cm} ; 5-2,110-112 \mathrm{~cm})$.

This core is, hence, of early Eocene age and is probably situated in the G. (M.) formosa Zone or the G. (M.) palmerae Zone (P.8-P.9). Based on the species present and a comparison with Site 245 , it is suggested that a middle Eocene age is excluded.

The highest samples in this Core $(5-2,30-32 \mathrm{~cm} ; 5-1$, $110-112 \mathrm{~cm}$; and $5-1,30-32 \mathrm{~cm}$ ), perhaps, already belong to the next sedimentary cycle revealed by Core 4 . Indeed, the 
Miocene element, proper to this latter core, is already represented in quantity (planktonic and benthonic species, including large Rupertina).

Samples examined:

$\begin{array}{ll}5, \mathrm{CC} & 5-4,52-54 \mathrm{~cm} \\ 5-6,110-112 \mathrm{~cm} & 5-3,110-112 \mathrm{~cm} \\ 5-5,70-72 \mathrm{~cm} & 5-2,110-112 \mathrm{~cm} \\ 5-4,120-122 \mathrm{~cm} & \end{array}$

\section{Biostratigraphic Summary}

For technical reasons, the Neogene was cored very discontinuously and core recovery was very poor; its history cannot be reconstructed in great detail. Planktonic foraminifera and nannofossils are abundant and richly diversified; they indicate a purely pelagic facies, even in the lowermost deposits of Core 4 where reworked older fossils and nearshore materials indicate a transgressive sea (early Miocene). During Miocene and Pliocene times, the sea bottom deepened progressively and the fauna are nearly all planktonic. Cores 1 through 4 can be assigned, respectively, to the Holocene, the early Pliocene, the early middle Miocene, and the lower part of early Miocene. Besides the planktonic assemblages, a considerable amount of shallowwater benthonics is present, which indicates the proximity of shallow areas, at least for the Quaternary. However, we must take into account that technical mixing during drilling processes can be responsible for contamination in the lower sediment. The upper part of Core 5 yields lowermost Miocene and/or uppermost Oligocene in a purely neritic facies with large miogypsinid foraminifera and Rupertia along with many shallow-water invertebrate remains. There are very few planktonic foraminifera and no nannofossils.

A large hiatus (15-30 m.y.) separates Neogene (and/or possibly uppermost Oligocene) and Eocene sequences. Eocene was cored continuously and provided shallow-water benthonic foraminifera (and ostracods), which are related either to neritic or to reefoid conditions; numerous fragments of bryozoa, echinoids, and other large organisms form the bulk of some washed residues. Nannofossils are very rare or missing; planktonic foraminifera are scarce, the most definitive ones were recovered in the lowest (11) and highest (5) cores of the Eocene sequence. They give, respectively, an early Eocene or latest Paleocene age and an early middle Eocene or late early Eocene age. Larger foraminifera agree with this age in Core 11 , which contains Nummulites and Discocyclina; on the contrary, Asterocyclina present in Cores 6 through 10 have a stratigraphic range that is too wide for any precise age determinations.

The construction of a sedimentation rate diagram for this site is hazardous, at least for the upper part of the hole where the sediment recovery was very poor and hampered by technical difficulties. From Recent to the early Pliocene, the construction of the sedimentation rate depends on two core catcher samples only. The rate of deposition is about $10 \mathrm{~m} / \mathrm{m} . \mathrm{y}$. Considering the position of the site on a plateau, this might be a reasonable value. During Miocene time, the constructed sedimentation rate-there are only a few core catcher or mixed samples-is strikingly small (3.5 to 6 $\mathrm{m} / \mathrm{m} . \mathrm{y}$.). There are two possible explanations for this reduced sedimentation: (1) the reworking, observed at an 130-meter hole depth, may have influenced the Miocene sedimentation throughout a long time interval; or (2) sedimentation was interrupted somewhere in the middle/late Miocene. Between early Eocene and early Miocene there is a large gap. The hole terminates at 194 meters in lower Eocene sediments. There, the highest sedimentation rate of this hole can be found with about 19 $\mathrm{m} / \mathrm{m} . \mathrm{y}$. This relatively high sedimentation rate-regarding the whole succession of this site-may be due to increased supply of detrital, fine-grained material, and volcanic ashes.

\section{CORRELATION OF REFLECTION PROFILES AND LITHOLOGIES}

The characteristics of the airgun reflection profile run by Glomar Challenger in the near-site area are to some extent quite similar to the data obtained by Gallieni in 1971 (Cruise 4). Both records show a series of well-stratified layers which more or less follow the gentle upward slope of the east flank of the Madagascar Ridge. The first reflector observed on the airgun record is at $0.13 \mathrm{sec}$ DT, the second, less distinct, reflector lies at about $0.25 \mathrm{sec}$ DT. A deeper reflector can vaguely be detected on the large scale original airgun record at about $0.33 \mathrm{sec}$ DT (Figure 8 ). This horizon corresponds on the flexotir record (Figure 2) to the top of the high velocity layer $(5 \mathrm{~km} / \mathrm{sec})$.

The lithologic description shows that the whole cored section can be subdivided into three lithostratigraphic units: (1) foram ooze with minor nanno-foram ooze, (2) shelly carbonate sand with glauconite shell-rich carbonate sand, and (3) glauconite-rich carbonate sand interbedded with volcanic sand and volcanic breccia. The boundary between Units I and II, at 125 meters depth, is defined by a highly lithified pebbly calcareous volcanic sandstone. The boundary between Units II and III, at about 176 meters depth, is marked by the appearance of the volcanic sandstone and volcanic breccia. The first reflector seen on the airgun record at $0.13 \mathrm{sec}$ DT could be correlated with the interface between Units I and II; in this case, the computed interval velocity is $1.92 \mathrm{~km} / \mathrm{sec}$, which is perhaps too large to support such a correlation. The boundary between Units II and III, at about 176 meters, cannot be correlated with the reflectors seen on the seismic profiler records. The second and third reflectors observed at $0.25 \mathrm{sec}$ DT and $0.33 \mathrm{sec}$ DT, respectively, were not reached by drilling.

Figure 8 shows the correlation which can be established between the reflection profiler records and the lithology

\section{SUMMARY AND CONCLUSIONS}

Sites 246 and 247 were drilled 8 miles apart, near the crest of the Madagascar Ridge, in Latitude $33^{\circ} 37^{\prime} \mathrm{S}$ (about 480 miles south of the Madagascar mainland). An east-west flexotir reflection and refraction profile at this latitude by Gallieni 4 in 1971 shows that the sediment of variable thickness ( 0.8 to $0.3 \mathrm{sec}$ DT) on the eastern flank and crest of the ridge is underlain by a layer of unknown thickness, having a measured sonic velocity of about $5 \mathrm{~km} / \mathrm{sec}$, which is either ridge basement or a superimposed layer of compact supracrustal rock. The high velocity layer is exposed on the sea floor near the ridge crest at about $44^{\circ} 45^{\prime} \mathrm{E}$. The objective of drilling a hole on the Madagascar Ridge was (a) to reach and sample the high velocity layer, and (b) to 


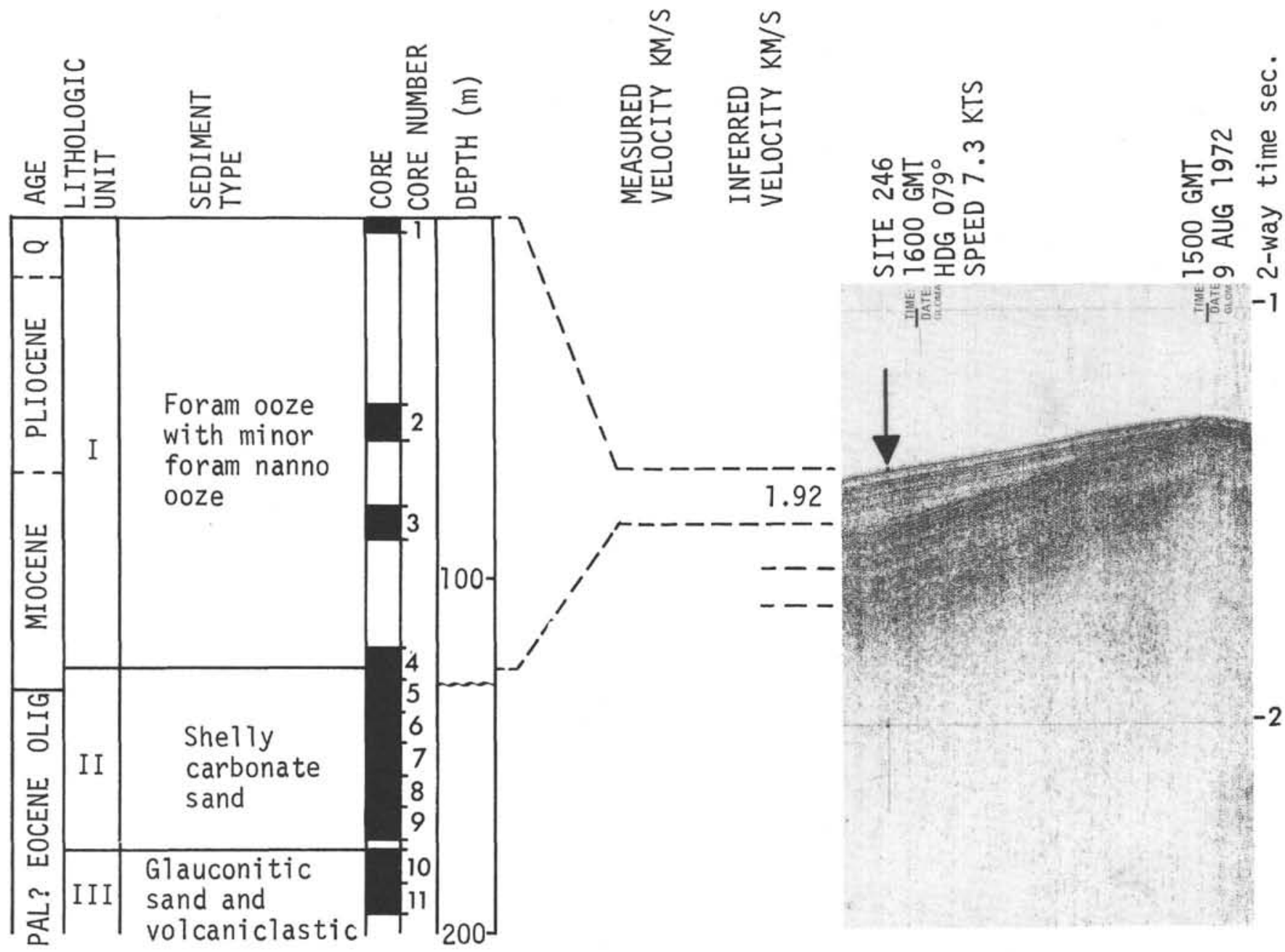

Figure 8. Correlation of seismic reflection profile with lithology. The wavy line in the depth column indicates a hiatus.

sample the younger sediments as completely as possible in order to establish a high latitude biostratigraphic succession above the CCD.

According to both the Gallieni flexotir record and the Glomar Challenger airgun profile, at the location finally selected for Site 246, the high velocity layer lies at about 0.33 sec DT depth; the overlying sediments show two clear internal acoustic reflectors at depths of $0.13 \mathrm{sec}$ DT and $0.25 \mathrm{sec}$ DT. The site is located in a water depth of 1030 meters, and the single hole penetrated 203 meters, of which only 94 meters was cored and 23.8 meters recovered. The low recovery was due to unstable hole conditions in unconsolidated sediment, which finally caused abandonment of the site on technical grounds before the scientific objectives had been realized. The scientific results are summarized in Figure 9. An attempt to drill an alternate hole (247) near the crest of the ridge, in 944 meters water depth and thinner sediment overlying the high velocity layer, was abandoned due to the inability of the drill to penetrate a hard layer at 26 meters depth with the bottom-hole assembly unsupported.

In spite of poor recovery, the 194-meter sediment section cored at Site 246 can be subdivided into three lithostratigraphic units which have an age range from Recent to early Eocene and possibly late Paleocene, including an unconformity representing about 25 m.y. hiatus between early Eocene and early Miocene/late Oligocene.

The uppermost Unit I is 125 meters thick and is represented by Quaternary to lower Miocene sand-size foram ooze with subordinate nanno-foram ooze containing megascopic fragments of pyrite in Core $3(80-89 \mathrm{~m})$. The surface punch-core sample contains 20 percent detrital silt in addition to shallow-water fauna derived from a shelf environment. The lower boundary of Unit I is marked by a highly lithified pebbly calcareous volcanic sandstone at a depth of 125 meters.

Lithologic Unit II is 51 meters thick and consists dominantly of unconsolidated shelly calcareous sand with up to 10 percent glauconite and not more than 20 percent detrital grains. The rich and diversified calcareous fauna is almost exclusively characteristic of a neritic or reefoidal environment and clearly indicates an early Eocene or early middle Eocene age for all but the uppermost few meters of Unit II. In spite of the lithological contrast with Unit I, the uppermost part of Unit II (as represented by Core 4) contains, among other things, a mixed assemblage of planktonic foraminifera, most of which are of early early Miocene age. In addition there is a much more restricted size range for the early Eocene foraminifera than is typical 


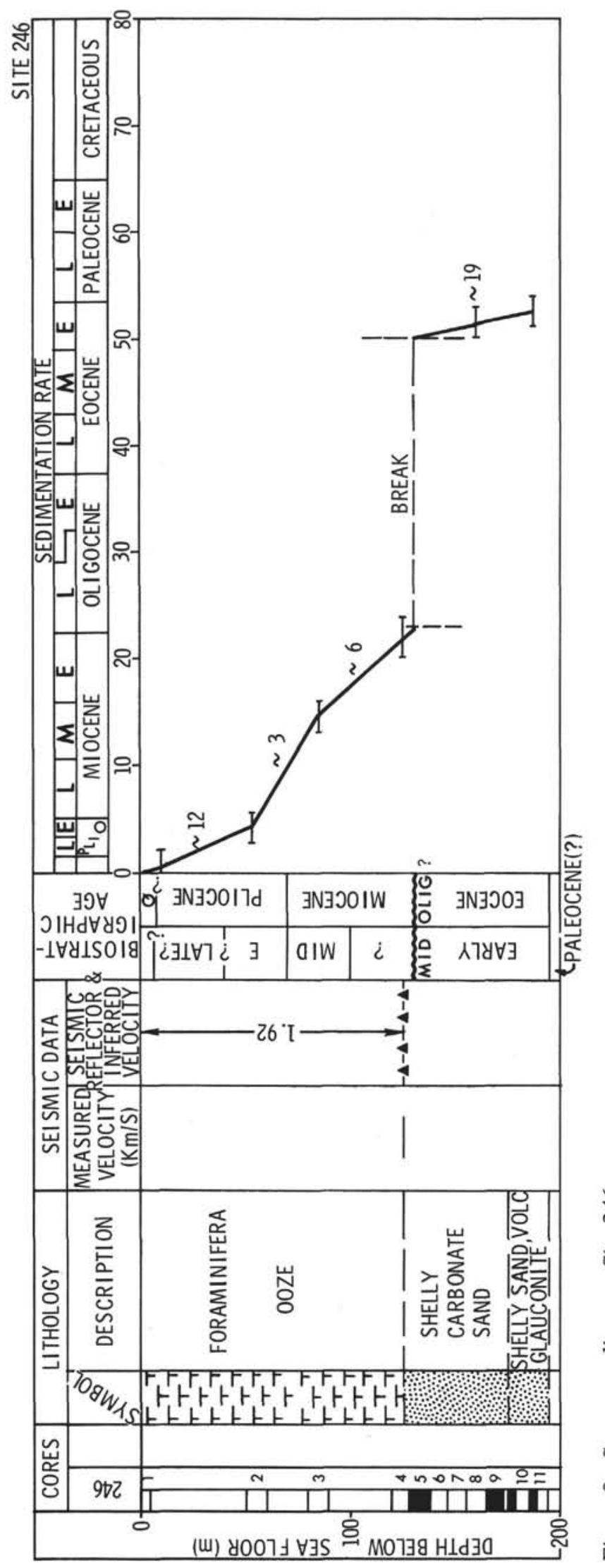

for the lower part of Unit II. It is evident that an unconformity representing a hiatus of about 27 m.y. (early Miocene to early Eocene) is present at this level in spite of no evidence for a lithological change.

Unit III was cored for 18 meters and is dominated by unconsolidated green glauconitic calcareous sands and shelly/zeolite-rich volcanic sand with thin $(0-5.3 \mathrm{~cm})$ layers of lithified volcanic sandstone and breccia. Silty clay, limestone, and volcanic ash beds are present in minor amounts. The oldest sediment cored, at a depth of 194 meters, was dated as early early Eocene ( $\sim 53$ m.y.), possibly uppermost Paleocene.

Bearing in mind that Site 246 at the present time lies only about 60 miles from the shallow area known as Walters Shoals (20 meters deep), which was undoubtedly exposed to subaerial erosion several times during the Pleistocene and possibly also during the Tertiary, the following geological history is indicated by the cored sequence:

1) Tne occurrence of a great variety of shallow-water benthonic fauna, crossbedded sands, and glauconite indicates that the sediments of Units II and III accumulateu in a moderately high energy, relatively shallow-water environment, less than about 300 meters deep, during the early Eocene. Terrigenous influx was certainly present but not at any time dominant.

2) A 27 m.y. hiatus followed early Eocene shallow-water sedimentation.

3) Reworking of the uppermost lower Eocene sediments ensued during an early Miocene marine transgression which left a pebbly calcareous sand layer that was formed under high energy shallow-water conditions. This occurred before subsidence of the sea floor, which commenced during the early Miocene and continued during the Pliocene, thereby allowing the formation of the almost totally planktonic deep-water biogenic sediments that are represented by Unit I.

4) During the Quaternary, the addition of a considerable amount of shallow-water benthonic fauna suggests the formation of a shallow-water environment in the vicinity and, probably, also an uplift of the site area to its present depth of 1000 meters.

\section{REFERENCES}

Francis, T. J. G. and Raitt, R. W., 1967. Seismic refraction measurements in the southern Indian Ocean: J. Geophys. Res., v. 72, p. 3015-3041.

Heezen, B. C. and Tharp, M., 1965. Physiographic diagram of the Indian Ocean (with descriptive sheet): New York (Geol. Soc. Am).

Laughton, A. S., Matthews, D. H., and Fisher, R. L., 1970. The structure of the Indian Ocean. In Maxwell, A. F. (Ed.), The Sea, v. 4, pt. 2, p. 543-586, New York (Interscience).

Porrenga, D. H., 1967. Glauconite and chamosite as depth indicators in the marine environment: Marine Geol., v. 5, p. 495-501.

Schlich, R., Delteil, J. R., Moulin, J., Patriat, Ph., and Guillaume, R., 1971. Mise en evidence d'une sedimentation de marge continentale sur le plateau de Kerguelen-Heard: Compt. Rendus Acad. Sci. Paris, v. 272 , p. $2060-2063$.

Udintsev, G. B., 1965. New data on the bottom topography of the Indian Ocean: Okeanologiya, v. 5, p. 993-998. 


\begin{tabular}{|c|c|c|c|c|c|c|c|c|c|}
\hline \multirow[b]{3}{*}{ 㟧 } & \multirow{2}{*}{ ZONE } & $\mathrm{Hol}$ & & & & re 1 & Cored Int & terval: & \multirow[b]{3}{*}{ LITHOLOGIC DESCRIPTION } \\
\hline & & \multicolumn{4}{|c|}{$\begin{array}{c}\text { FOSSIL } \\
\text { CHARACTER } \\
\end{array}$} & & \multirow[b]{2}{*}{ LITHOLOGY } & \multirow{2}{*}{ 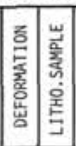 } & \\
\hline & 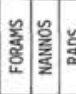 & 瓷 & $\frac{8}{2}$ & a & & & & & \\
\hline 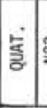 & 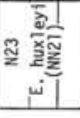 & & Ae- & \multicolumn{2}{|c|}{ Rf } & & 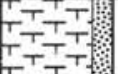 & \multirow[t]{2}{*}{$-c c$} & \multirow{2}{*}{ 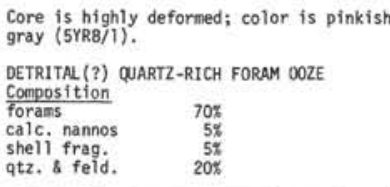 } \\
\hline & & & & & & & & & \\
\hline
\end{tabular}

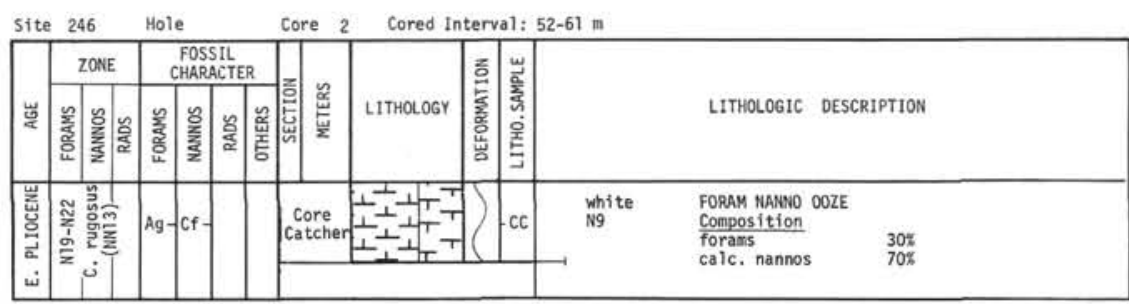

\begin{tabular}{|c|c|c|c|c|c|c|c|c|c|c|}
\hline site & \multicolumn{2}{|c|}{246} & \multicolumn{3}{|c|}{ Hole } & \multicolumn{2}{|c|}{ Core 3} & \multicolumn{2}{|c|}{ Cored Interval: $80-89 \mathrm{~m}$} & \multirow[b]{3}{*}{ LITHOLOGIC DESCRIPTION } \\
\hline \multirow[b]{2}{*}{ ๘ } & & ZONE & & $\begin{array}{l}\text { FOSS } \\
\text { CHARA }\end{array}$ & STCTE & & & & z & \\
\hline & $\mid$ & 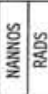 & 章 & 惫 & $\underline{\xi}$ & 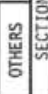 & 氕 & LITHOLOGY & 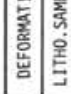 & \\
\hline \multirow{3}{*}{\multicolumn{2}{|c|}{ 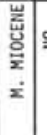 }} & & & & & \multirow{3}{*}{\multicolumn{2}{|c|}{$\begin{array}{c}\text { core } \\
\text { catche }\end{array}$}} & \multirow{3}{*}{ 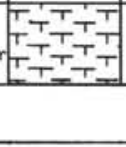 } & \multirow{3}{*}{$-\mathrm{cc}$} & \multirow{3}{*}{$\begin{array}{l}\text { Color is pinkish gray (5YR8/1) } \\
\text { FoRAM OOzE } \\
\text { Composition } \\
\text { forams } \\
\text { calc. nannos }\end{array}$} \\
\hline & \multirow{2}{*}{9} & & & & & & & & & \\
\hline & & & & & & & & & & \\
\hline
\end{tabular}

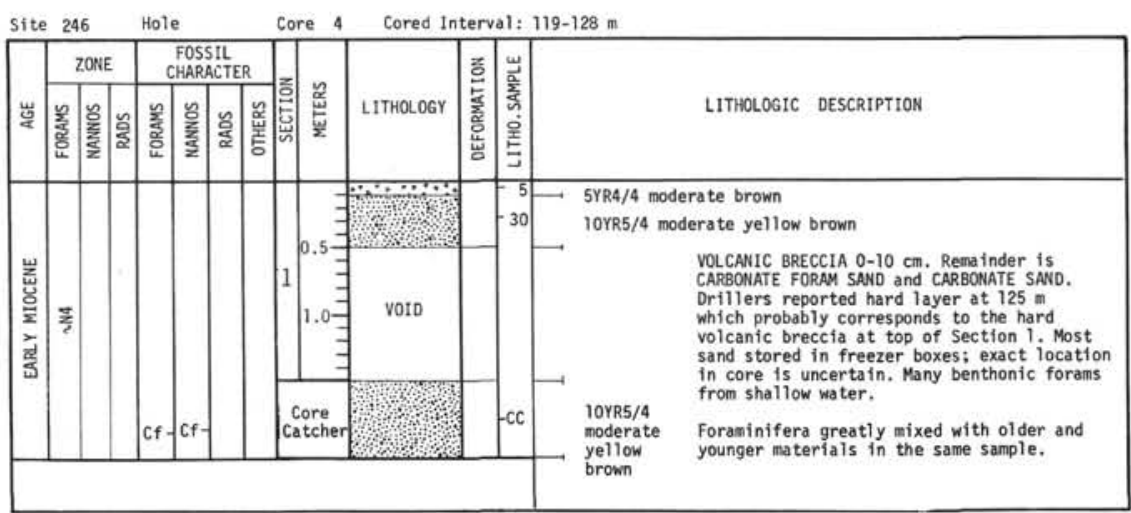

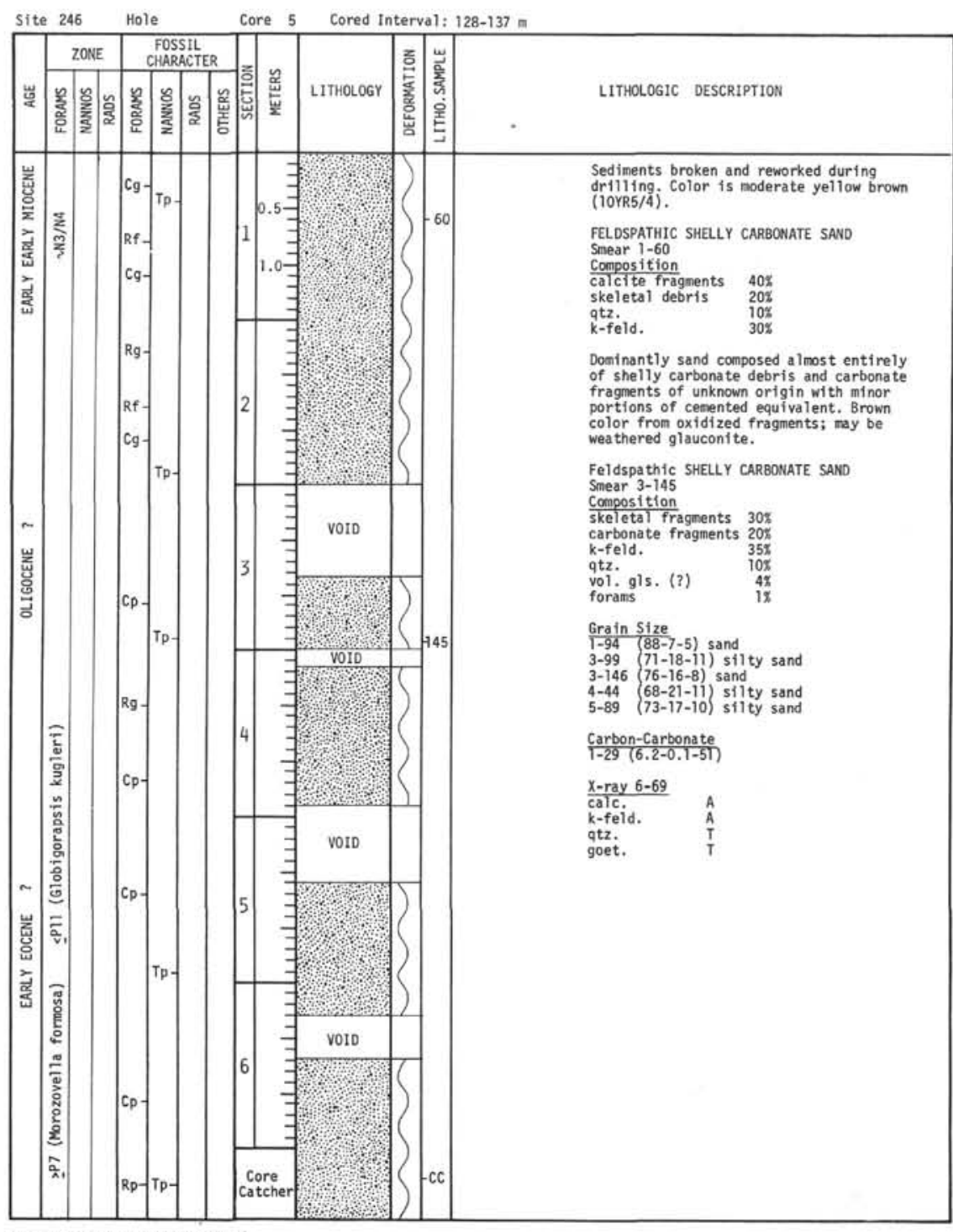

Explanatory notes in chapter 1 


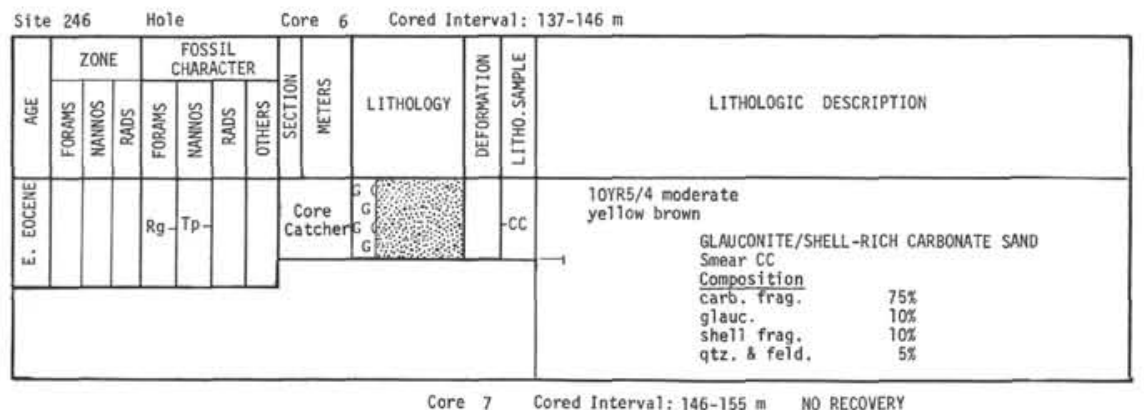

core 7 Interval: $155-164 \mathrm{~m}$

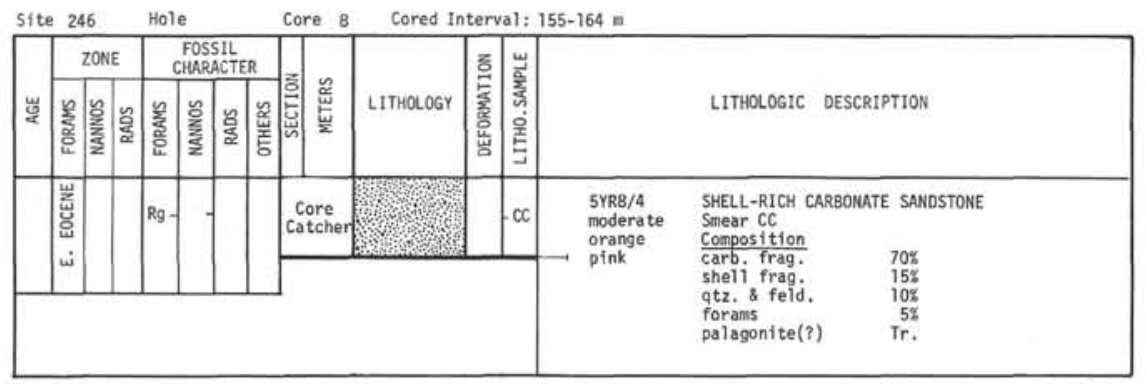

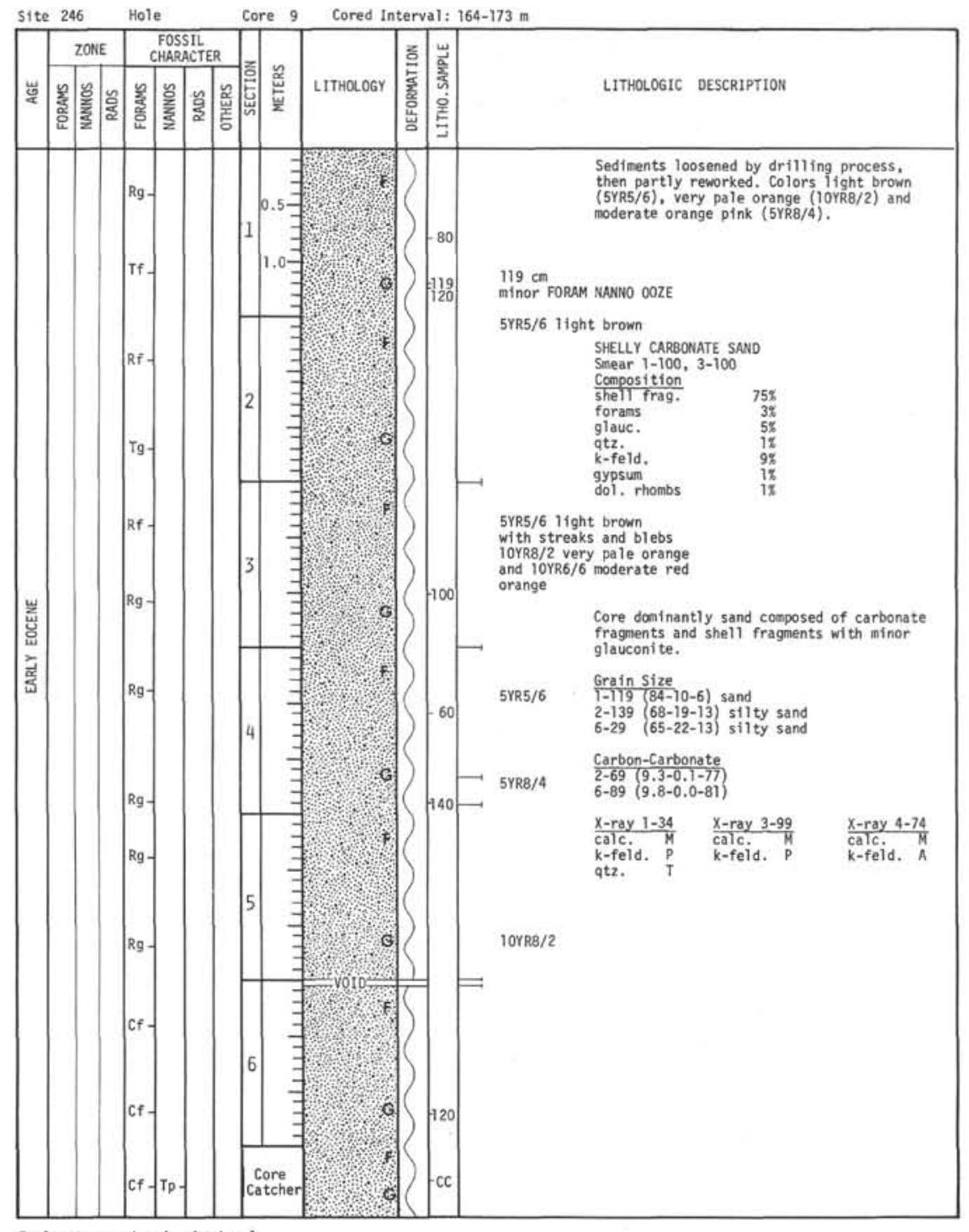




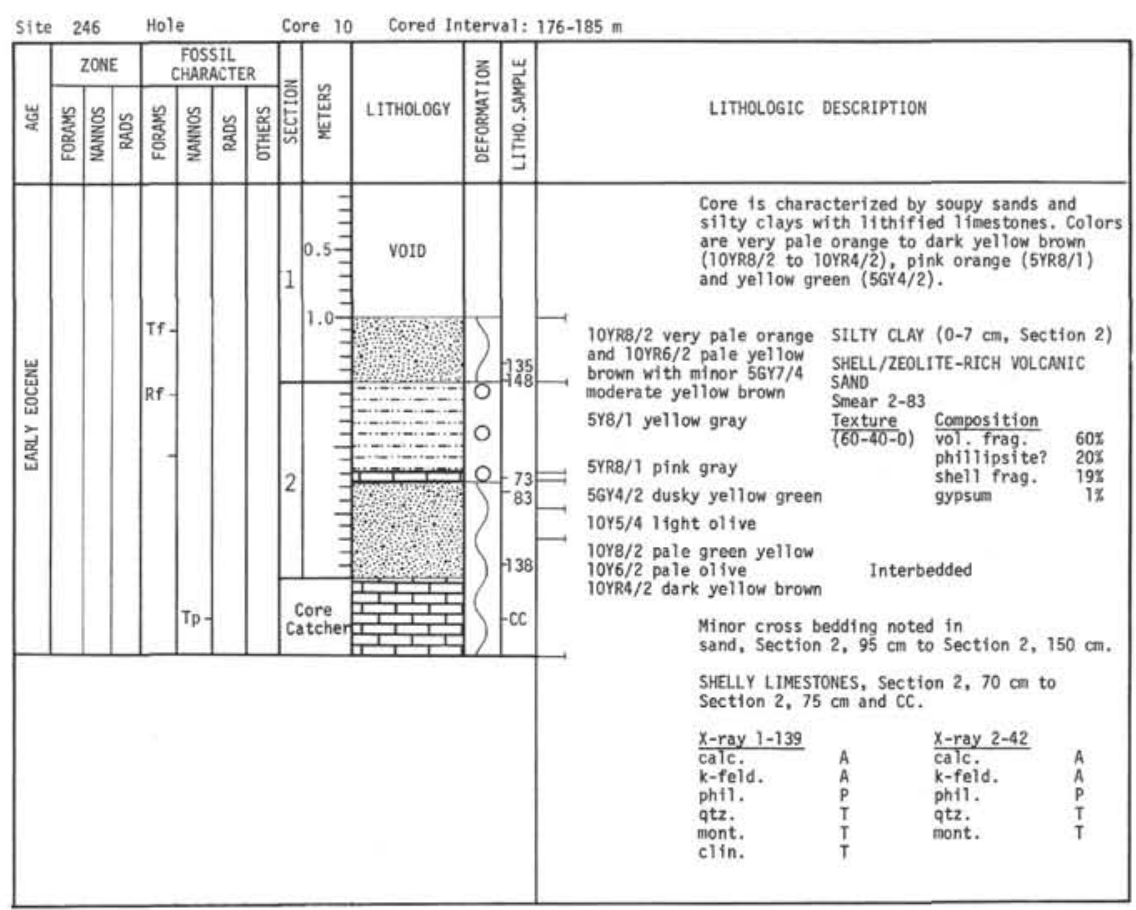

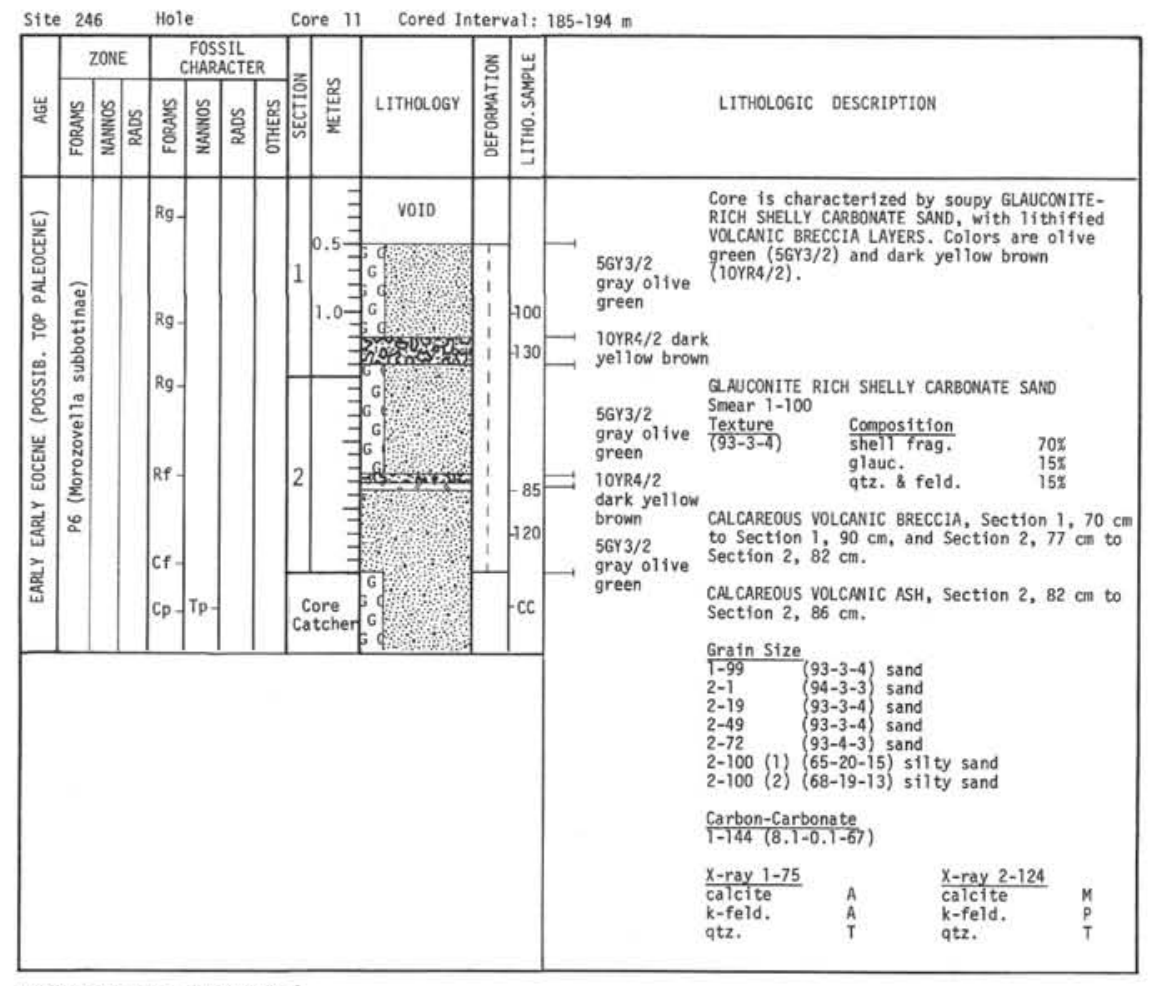

Explanatory notes in chapter 1 


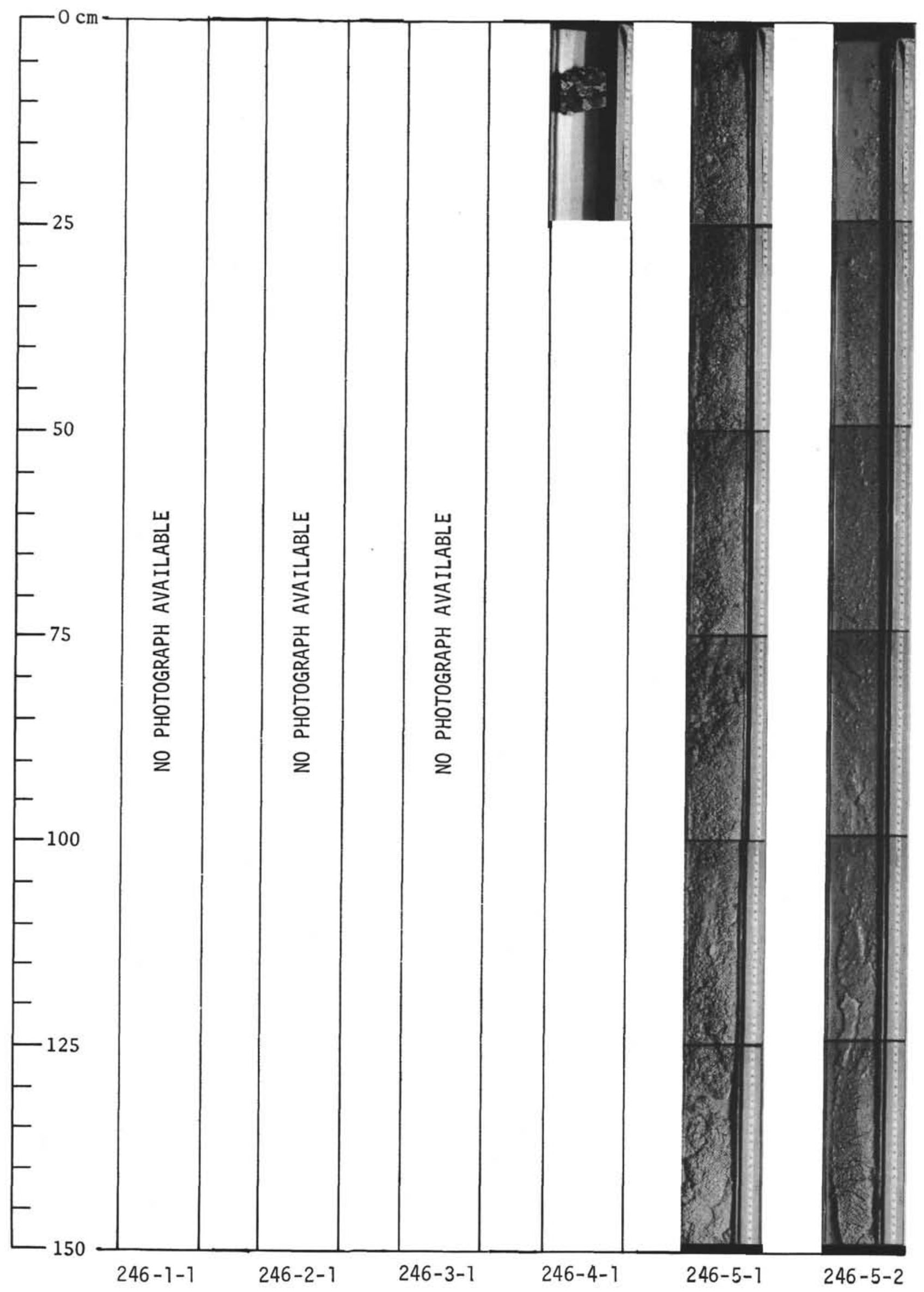




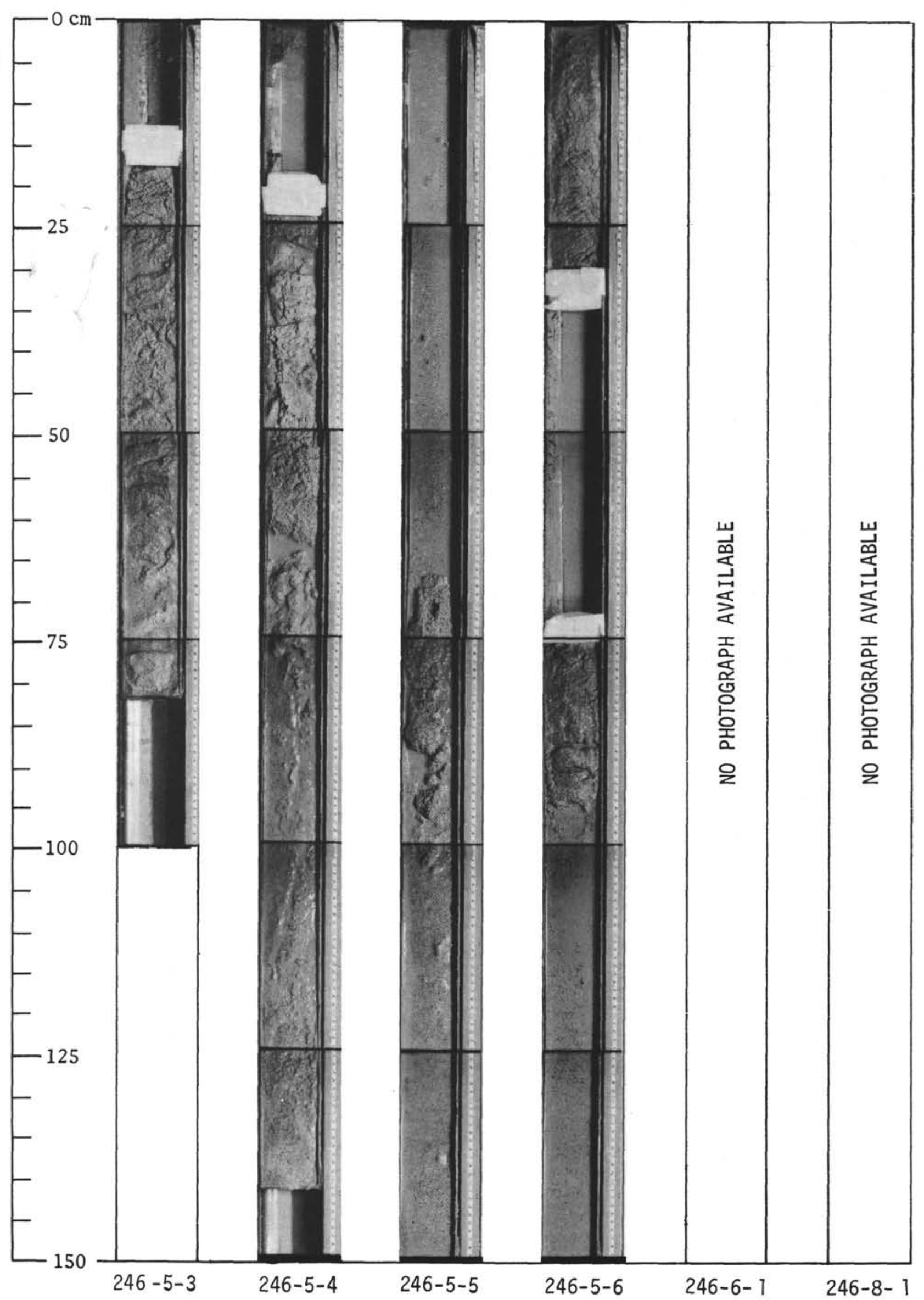




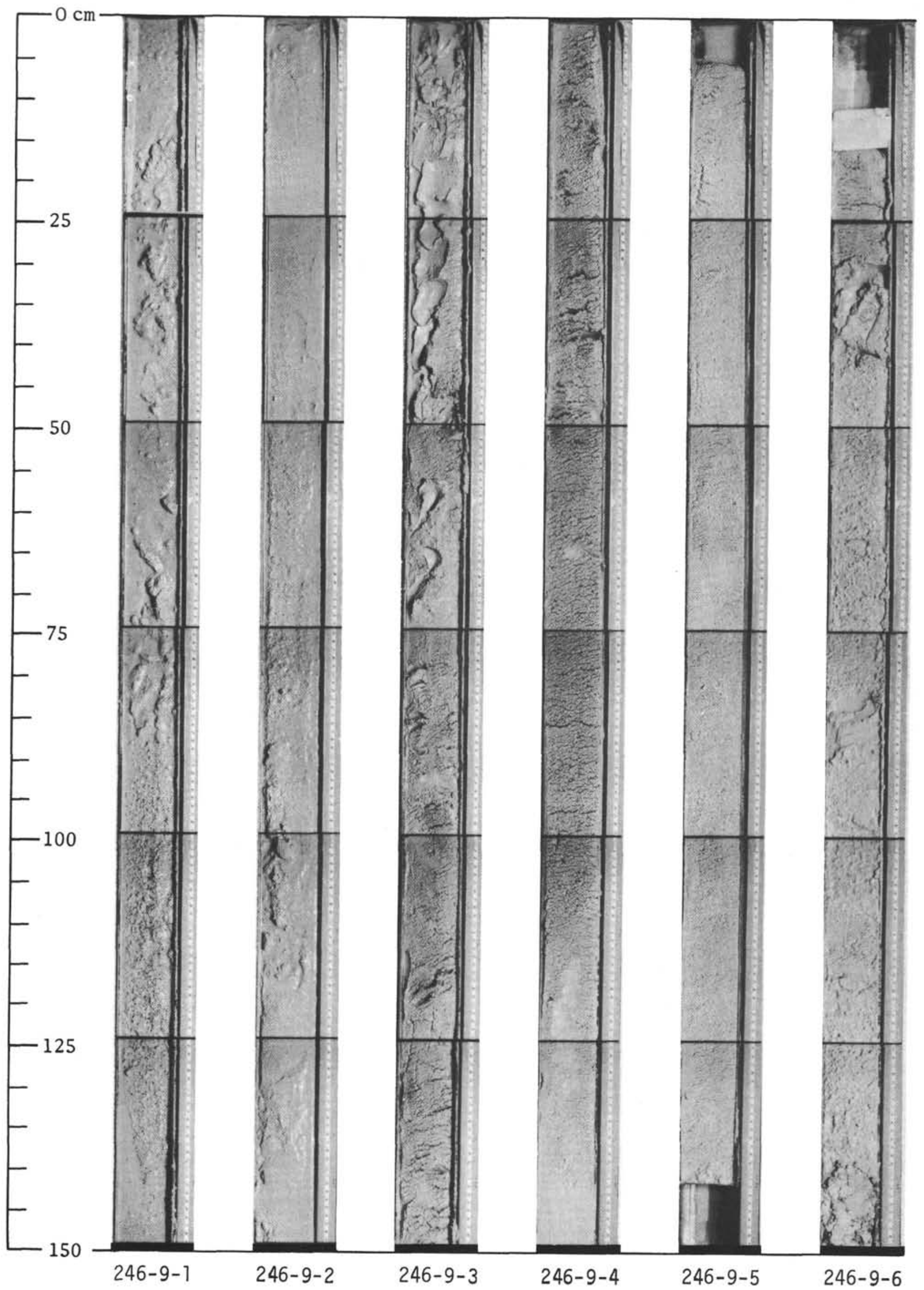




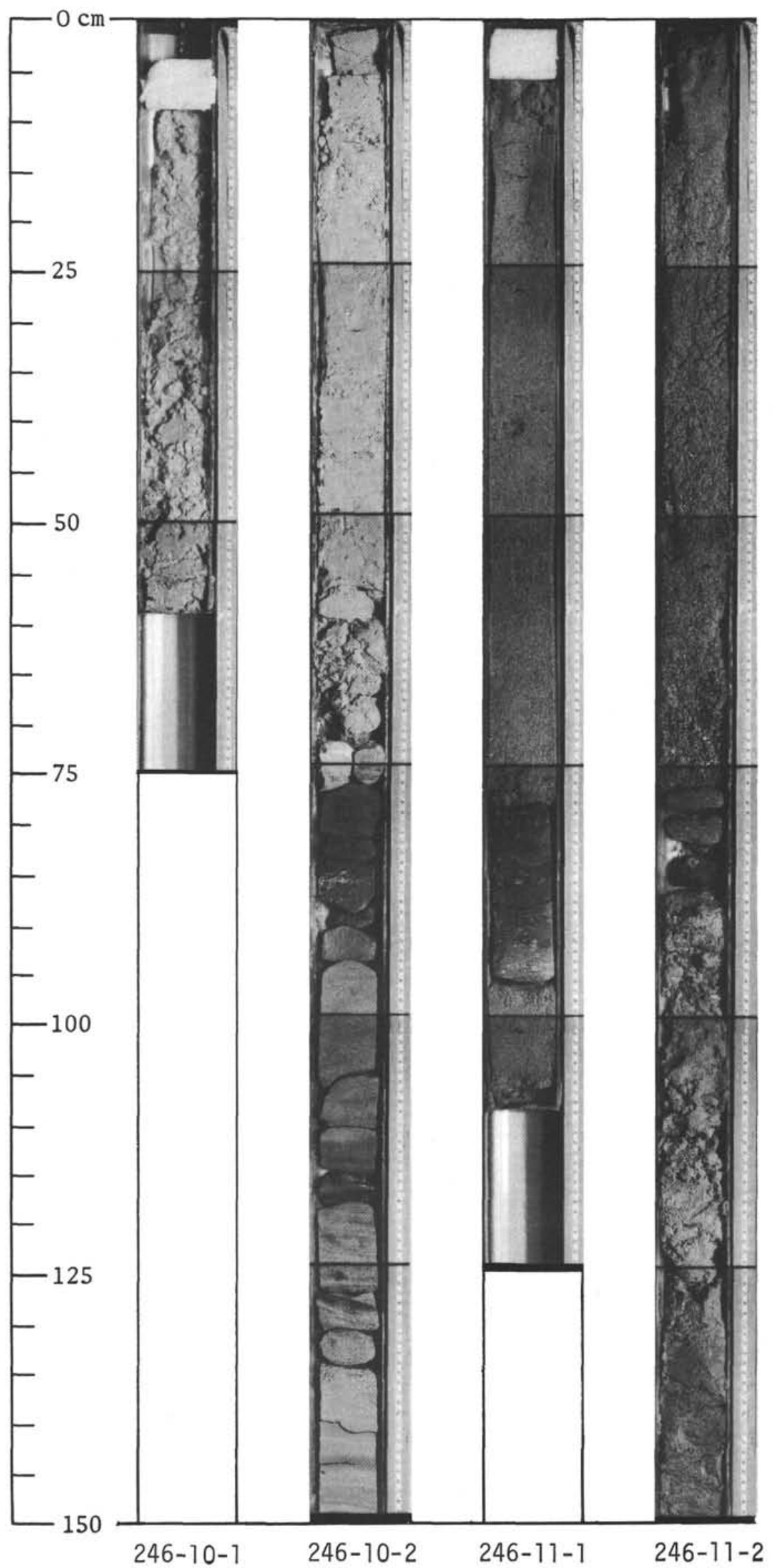

